\title{
Irony and Identity: Music Manuscripts from the Auschwitz-Birkenau State Museum
}

\author{
PATRICIA HALL
}

\begin{abstract}
The Collections Department of the Auschwitz-Birkenau State Museum retains many arrangements of popular songs that were performed by the men's orchestra of Auschwitz I. These songs often bear highly ironic but tragically relevant titles: "Letters That Never Arrived," "Hours That One Can Never Forget," "Sing a Song When You're Sad." A number of these songs are in the form of manuscript parts, written with great care in black ink on Beethoven Papier brand music paper. In this essay, I examine the manuscript parts for one of these songs, "Die schönste Zeit des Lebens" (The Most Beautiful Time of Life), to learn more about the identity of the prisoner copyists and how these songs might have functioned in a concentration camp.
\end{abstract}

The Collections Department of the Auschwitz-Birkenau State Museum retains many arrangements of popular songs that were performed by the men's orchestra of Auschwitz I. ${ }^{1}$ These songs often bear highly ironic but tragically relevant titles: "Letters That Never Arrived," "Hours That One Can Never Forget," "Sing a Song When You're Sad." A number of these songs are in the form of manuscript parts, written with great care in black ink on Beethoven Papier brand music paper. In this essay, I examine the manuscript parts for one of these songs, "Die schönste Zeit des Lebens" (The Most Beautiful Time of Life), to learn more about the identity of the prisoner copyists and how these songs might have functioned in a concentration camp.

In Music of Another World, Szymon Laks, one of the conductors of the men's orchestra in Birkenau (Auschwitz II), described how musician deaths and hospitalizations forced him to use odeon, a music notation "which makes it possible for any group to perform any work regardless of the presence or absence of one or even a few musicians." ${ }^{2}$ The constantly changing membership of the men's orchestra in Auschwitz I, due to illness, selections, suicides, murder, releases, and transfers to other camps, would make it challenging to identify the members of the orchestra during any period of its existence. (In fact, there is only one surviving document listing the members of the Auschwitz I men's orchestra, but it is dated November $21,1944$, after most of the original prisoners in the orchestra were transferred to other camps. $)^{3}$ The manuscripts of the popular songs, however, are occasionally signed with prisoner numbers, which can be linked to names and dates of imprisonment. In the second half of this essay, I look for similar clues in other

\footnotetext{
${ }^{1}$ I would like to thank the Collections Department of the Auschwitz-Birkenau State Museum for giving me access to these materials during my numerous trips to Oswiecim. I especially thank Jan Kaplon for making these intense periods of study so productive.

${ }^{2}$ Szymon Laks, Music of Another World (Evanston, IL: Northwestern University Press, 1989), 48.

${ }^{3}$ Archives of the Auschwitz-Birkenau State Museum, D-Au I-3a/363, Arbeitseinsatz, vol. 4, pp. 391-92, published in Jacek Lachendro, "The Orchestras in KL Auschwitz," Auschwitz Studies 27 (2015): 7-148. I would like to thank Szymon Kowalski of the Auschwitz-Birkenau State Museum for meeting with me and sending me this document, as well as the many others appearing in this article.
} 
manuscripts at the Auschwitz-Birkenau State Museum to establish a chronology and identify additional prisoners who created these song arrangements.

\section{Auschwitz and the Archival Experience}

Even before reaching the archive, the Auschwitz-Birkenau State Museum immerses you in the daily life of the prisoner musicians. To reach the archive, one must walk through the Arbeit Macht Frei gate and the location to the right where the men's orchestra played as prisoners marched to and from work (Figure 1).

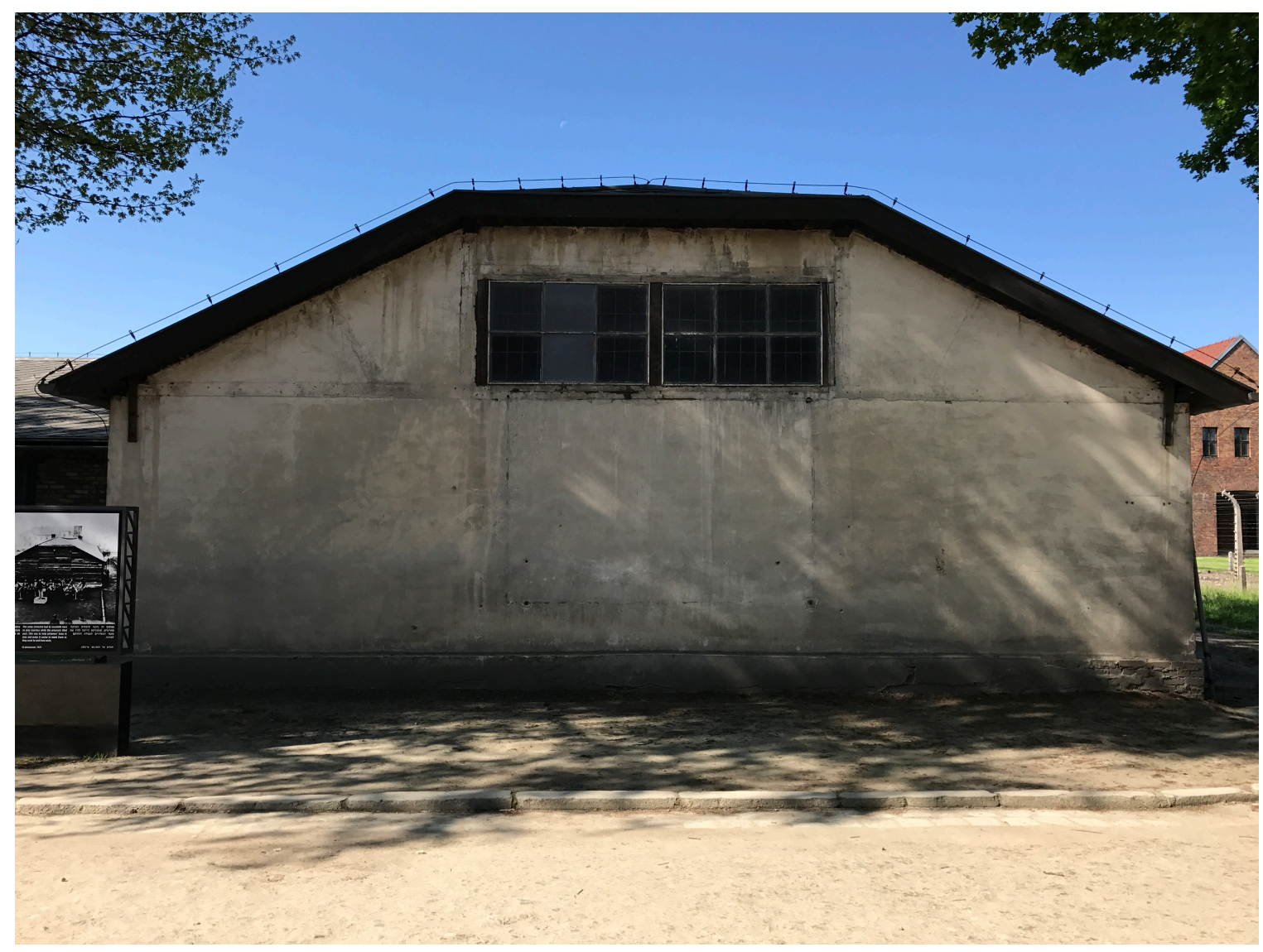

Figure 1: Location where the Auschwitz I men's orchestra played near the "Arbeit Macht Frei" gate (author's photo).

A sign posted here shows a 1941 photograph of the men's orchestra playing for one of the Sunday concerts (Figure 2). Approximately twenty-five musicians are visible, playing for groups of fellow prisoners. ${ }^{4}$ Block 24, on the left, housed the music room, used for rehearsals, concerts, storing instruments, and copying music. (The upper floor, oddly enough, was the camp bordello.) Here another sign posts a drawing of the men's orchestra playing as exhausted prisoners marched back from their outside work details, forced to remain in step with the orchestra while carrying the corpses of men who had died during the day (Figure 3).

\footnotetext{
${ }^{4}$ See Hubert Szczęśniak's detailed analysis of this photo in "Musical Sources Survived in the Collection of the AuschwitzBirkenau State Museum,” Kwartalnik Młodych Muzykologów UJ 35 (2017): 136, www.ejournals.eu/kmmuj.
} 


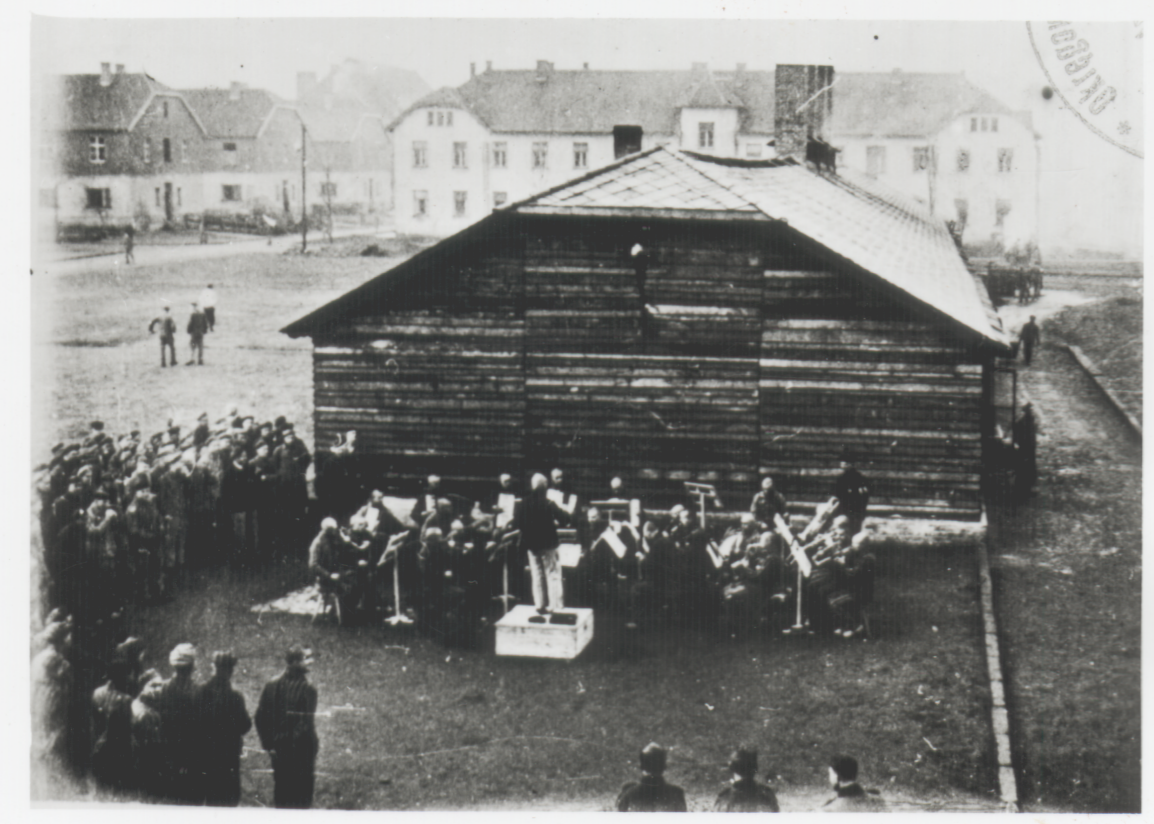

Figure 2: 1941 photograph of the same location. The Auschwitz I men's orchestra playing a Sunday concert for inmates. Archive of the Auschwitz-Birkenau State Museum, Negative nr. 00337.

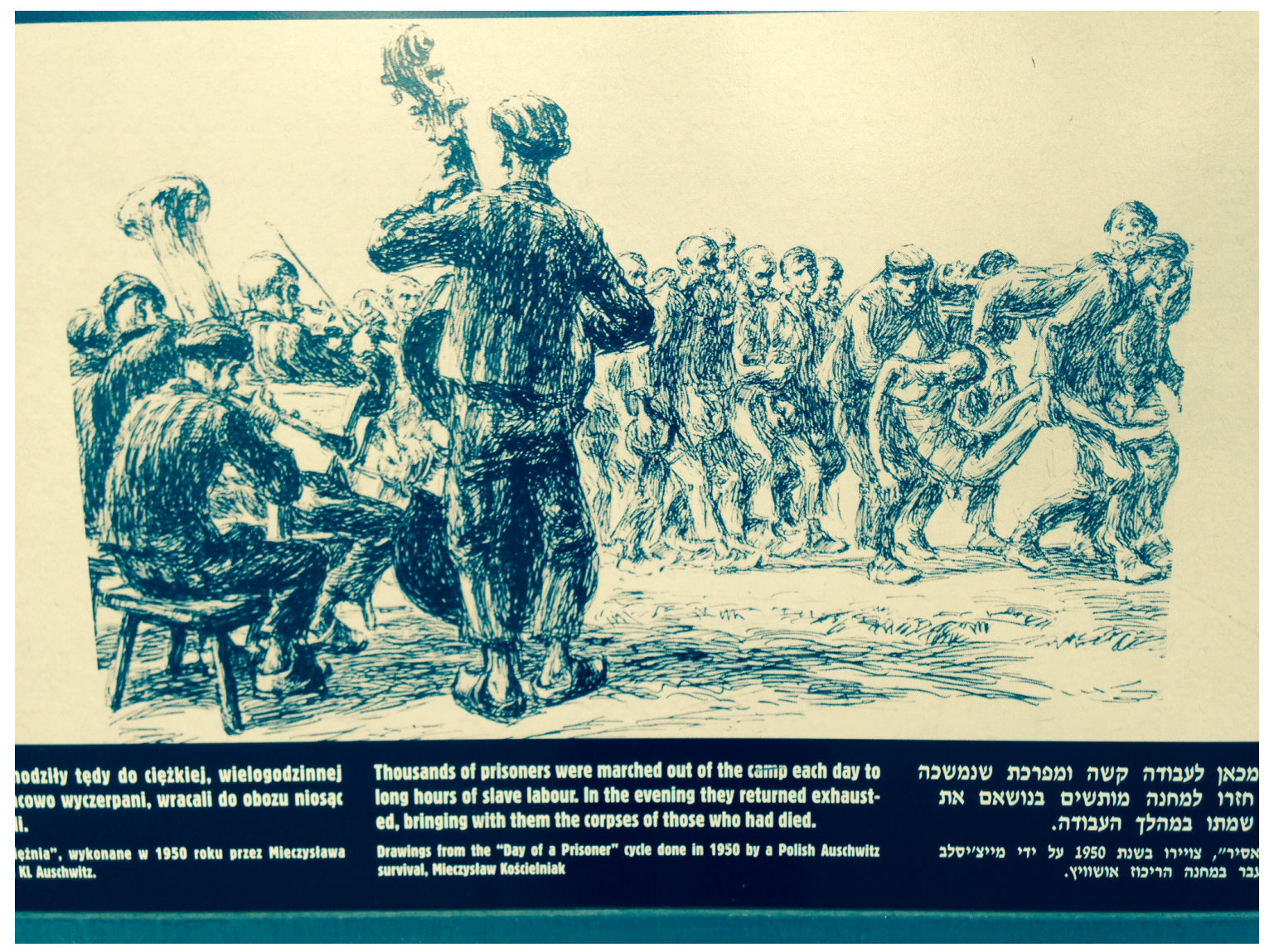

Figure 3: Sign near Block 25 showing Mieczyslaw Kościelniaka's drawing of part of the Auschwitz I men's orchestra playing as prisoners return from work (author's photo). 
According to Augustyn Bartusik, a musician in the men's orchestra until 1943, thirty to forty men died on work details per day. ${ }^{5}$ The Collections Department itself is in Block 25, the upper floor of which served as sleeping quarters for many of the musicians (Figure 4).

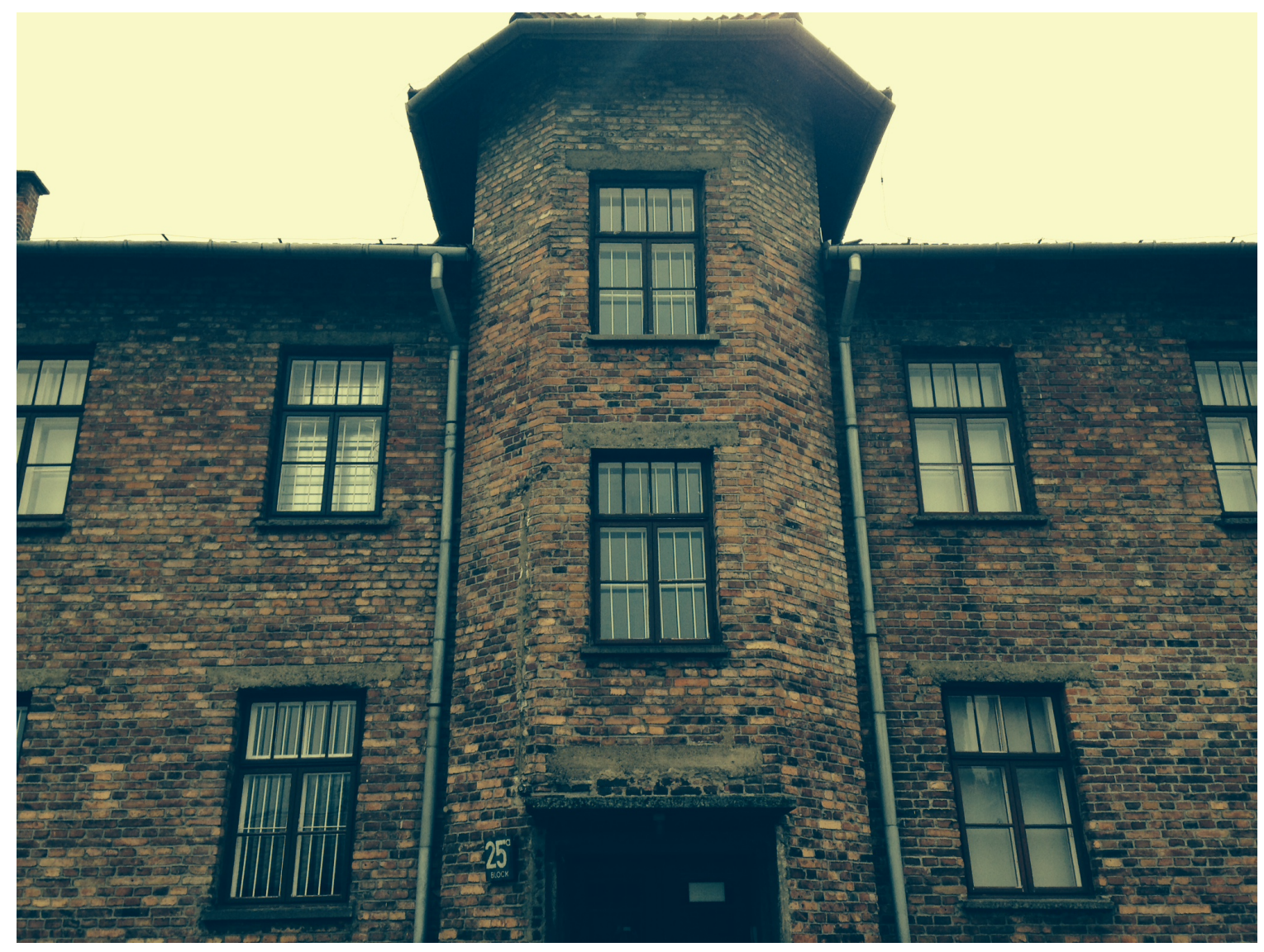

Figure 4: Block 25, the location of the Collections Department of the Auschwitz-Birkenau State Museum (author's photo).

This building is also visible in the background of Figure 2. Although no longer painted white, the exterior is essentially the same as in the 1940s, and the hallways retain the original, highly worn tile floors. The music collection, like most of the documents preserved by the museum, is incomplete. The manuscript parts for "Die schönste Zeit des Lebens," for instance, as well as the other manuscripts discussed in this article, were donated to the museum on October 24, 1975, thirty years after the end of World War II by Wiktor Zieliński, a member of the Polish militia stationed at Oświęcim. ${ }^{6}$

\section{The Auschwitz Foxtrot}

Originally a 1941 popular song composed by the German film composer Franz Grothe with a text by Willi Dehmel, "Die schönste Zeit des Lebens" has been arranged for a small ensemble of fourteen

\footnotetext{
${ }^{5}$ From the Auschwitz Chronicle, DVD, Auschwitz-Birkenau State Museum, 2015.

${ }^{6}$ See the report by Wiktor Zieliński, Statements Unit, Auschwitz-Birkenau State Museum, vol. 84, pp. 112-16, discussed by Hubert Szczęśniak in "Musical Sources Survived in the Collection of the Auschwitz-Birkenau State Museum," 133-34.
} 
instruments: four first violins, five second violins, a viola, two clarinets, a trombone, and a tuba. ${ }^{7}$ Although the original printed score is missing, a source in the Franz Grothe Archive in Berlin reveals that the Auschwitz-Birkenau parts are derived from Friedrich Meyer's foxtrot arrangement (Figure 5).

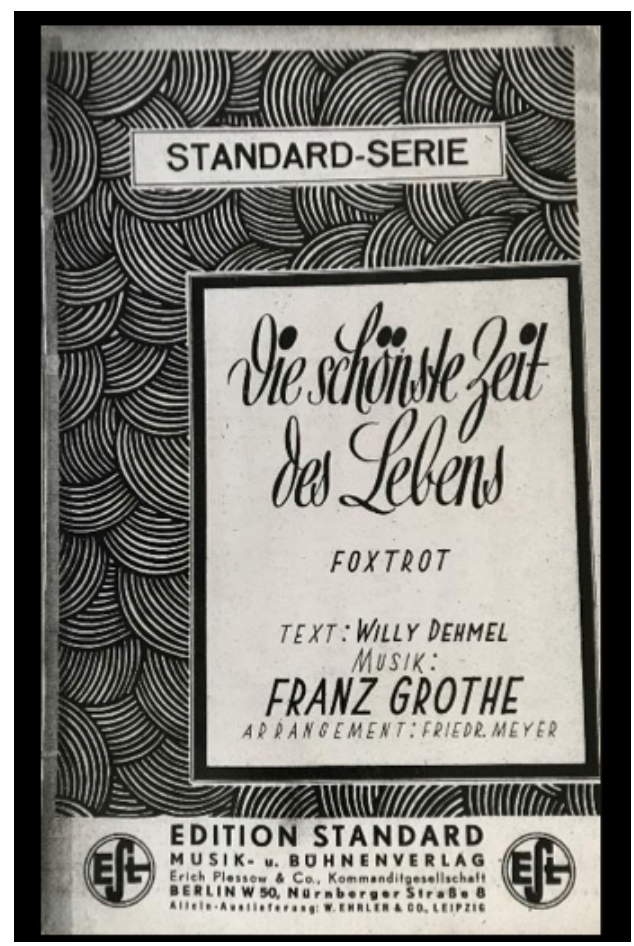

Figure 5: Cover of "Die schönste Zeit des Lebens" arranged by Friedrich Meyer.

This foxtrot was originally arranged for a dance band: voice, guitar, percussion, piano, trombone, first, second, and third violins, cello, bass, first and second trumpet, two tenor saxophones, and three alto saxophones. ${ }^{8}$ All the manuscript parts in the Collections Department bear the designation "Foxtrot," and the characteristic LONG-short-short rhythm appears throughout the song.

"Die schönste Zeit des Lebens" is a song about falling in love in the month of May, when "a mysterious magic lies in the air! The world is full of music and tender fragrance." Like many of the other popular songs in the archive of the Auschwitz-Birkenau State Museum, it describes an atmosphere about as far from a concentration camp as one could imagine. Here is the complete text of the song:

Die schönste Zeit des Lebens beginnt im Monat Mai:

Die Welt ist voll Musik und zärtlichem Duft!

Wer dann nicht ganz aus Stein ist, verliert sein Herz dabei:

Ein rätselhafter Zauber liegt in der Luft!

Und aus manchen kürzen schönen Sekunden

werden viele lange glückliche Stunden!

Die schönste Zeit des Lebens beginnt im Monat Mai;

doch wann sie für uns enden soll, bestimmen nur wir zwei!

\footnotetext{
${ }^{7}$ For biographical information and a catalogue of his compositions, see Franz Grothe Werkverzeichnis, Neue erweiterte Ausgabe (Munich: Buch \& Media GmbH, 2008).

${ }^{8}$ I would like to thank Alexander Schatte, Director of the Archiv der Franz Grothe-Stiftung for making me aware of this arrangement and kindly sending me a copy of the parts.
} 
The most beautiful time of life begins in the month of May:

The world is filled with music and tender fragrance.

Whoever isn't then made completely of stone loses his heart thereby:

A mysterious magic lies in the air!

And many short, delightful seconds,

become many long, happy hours!

The most beautiful time of life begins in the month of May;

However, when it should end for us, only we decide! ${ }^{9}$

Three copyists have written out the fourteen parts for the foxtrot. Each has a distinct musical script; moreover, two of the three copyists sign parts with their prisoner number. The first, number 5665, Antoni Gargul, was a clarinetist and violist, and one of the founding members of the Auschwitz I orchestra (Figure 6). ${ }^{10}$ Like many of the first prisoners in the camp, he was a Polish soldier-a sergeant in the Twentieth Krakow Infantry Regiment. He arrived in the camp on October 8, 1940, and was released three years later on October 14, 1943. ${ }^{11}$

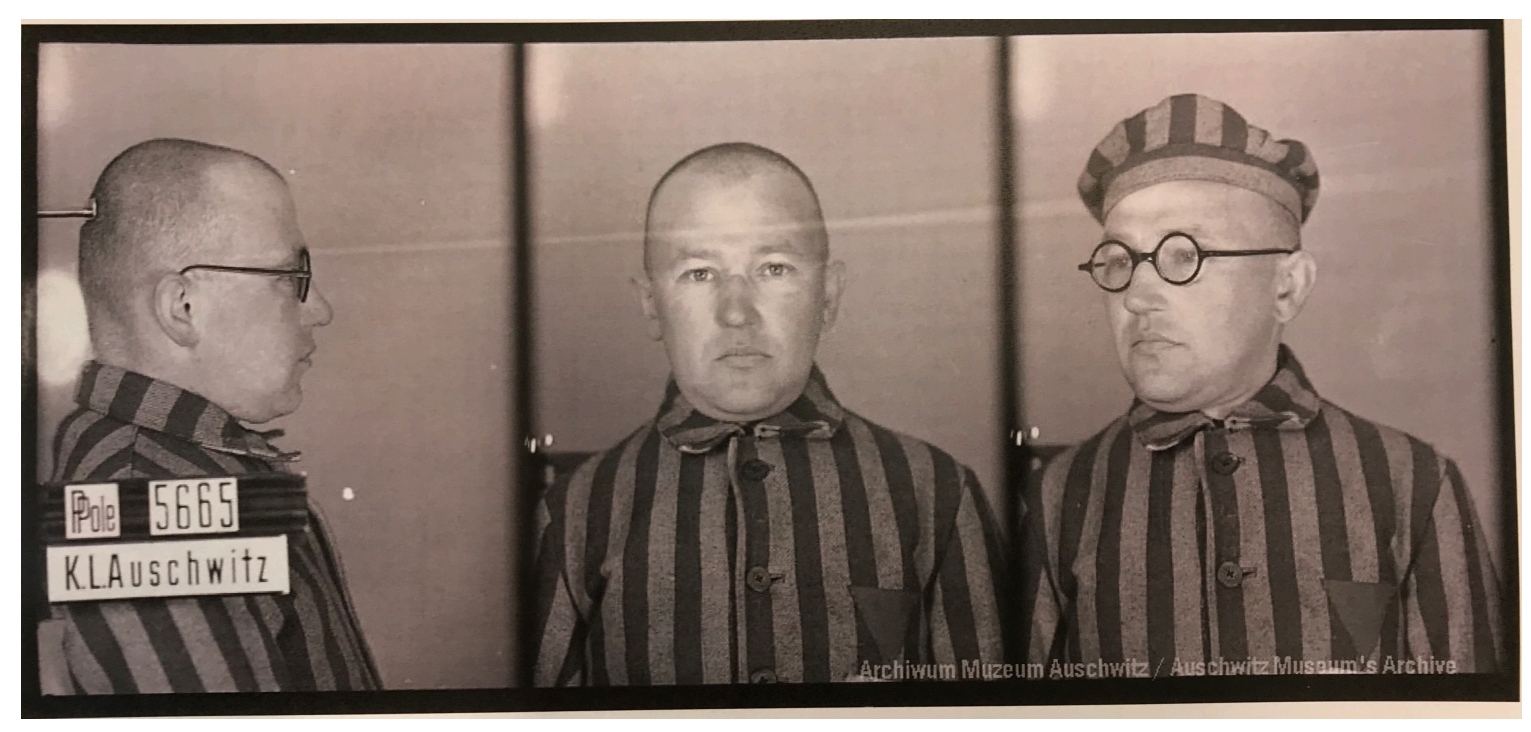

Figure 6: Prisoner photo of Antoni Gargul, number 5665. Archive of the Auschwitz-Birkenau State Museum.

According to Adam Kopyciński, who became conductor of the men's orchestra in 1944, "One day he requested that he be allowed to bring several instruments from home, on which marches could be played. As it was marches, the Germans couldn't refuse, and he received permission." ${ }^{12}$ His musical script is immediately discernable by its large, horizontal note heads, unusual quarter note rests, and multiple vertical dividing lines between sections (Figure 7).

\footnotetext{
${ }^{9}$ I would like to thank my former colleague, Lee Rothfarb, for his helpful comments on this translation.

${ }^{10}$ Ignacy Szczepański, Häftlingskapelle (Warsaw: Książka I Wiedza, 1990), 31, 91.

${ }^{11}$ Szczepański, Häftlingskapelle, 91; and "Prisoners," database of the Auschwitz-Birkenau State Museum, http://auschwitz.org/en/museum/auschwitz-prisoners/.

${ }^{12}$ From the Auschwitz Chronicle (Auschwitz-Birkenau State Museum, 2015), DVD.
} 


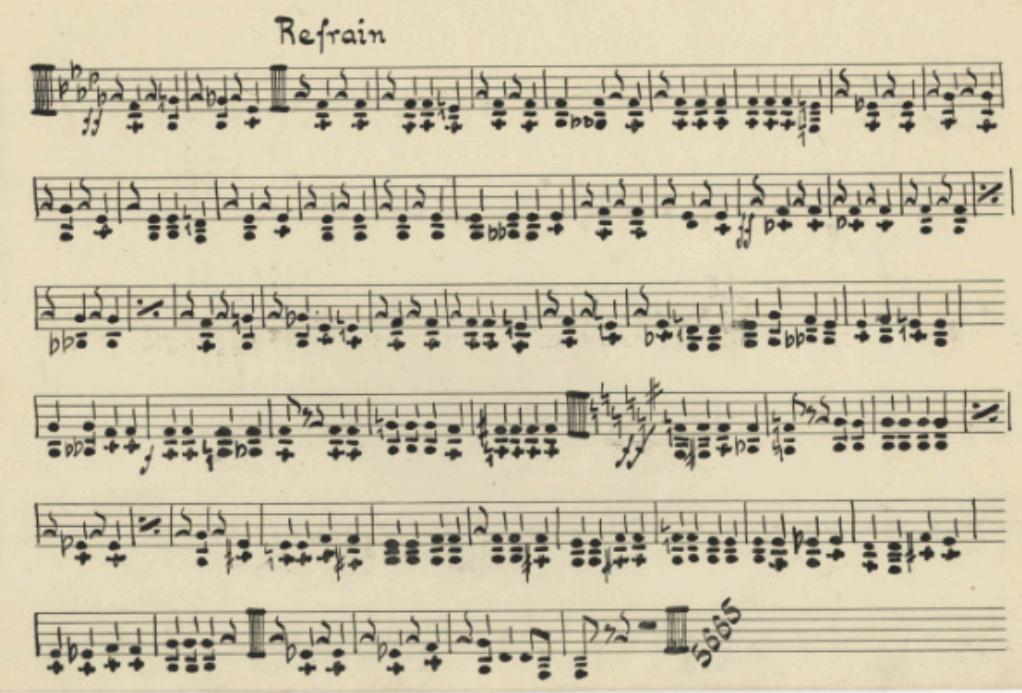

Figure 7: Viola part of “Die schönste Zeit des Lebens” completed by Antoni Gargul (PMO II-4-357/20v).

The second copyist, number 5131, Maksymilian Piłat, arrived even earlier in the camp, on September 22, 1940. Like many of his Polish colleagues in the orchestra, he was transferred to a concentration camp in Germany (Oranienburg-Sachsenhausen) in October, $1944 .{ }^{13}$ We do not have a prisoner photograph of Piłat, but fortunately the artist and fellow prisoner Szczepan Andrzejewski created a portrait of him in 1944 (Figure 8). ${ }^{14}$ Piłat was a bassoonist and graduate of the Warsaw Conservatory. (He also played clarinet and oboe.) After the war, he played in the Breslau Orchestra, and beginning in 1953 in the orchestra of the State Opera and Baltic Philharmonic in Gdansk. ${ }^{15}$ Figure 9 shows a clarinet part in Piłat's handwriting. Note that his quarter note rests have a characteristic "V" shape. (He is the only copyist who writes quarter note rests in this manner.)

\footnotetext{
13 "Prisoners," database of the Auschwitz-Birkenau State Museum, http://auschwitz.org/en/museum/auschwitz-prisoners/.

${ }_{14}^{14}$ PMO-I-1-33. Reproduced in Kunst in Auschwitz 1940-1945 (Berlin: Rasch Druckerei und Verlag, 2005), 315.

${ }^{15}$ Ibid., 314. Szczepański, Häftlingskapelle, 50.
} 


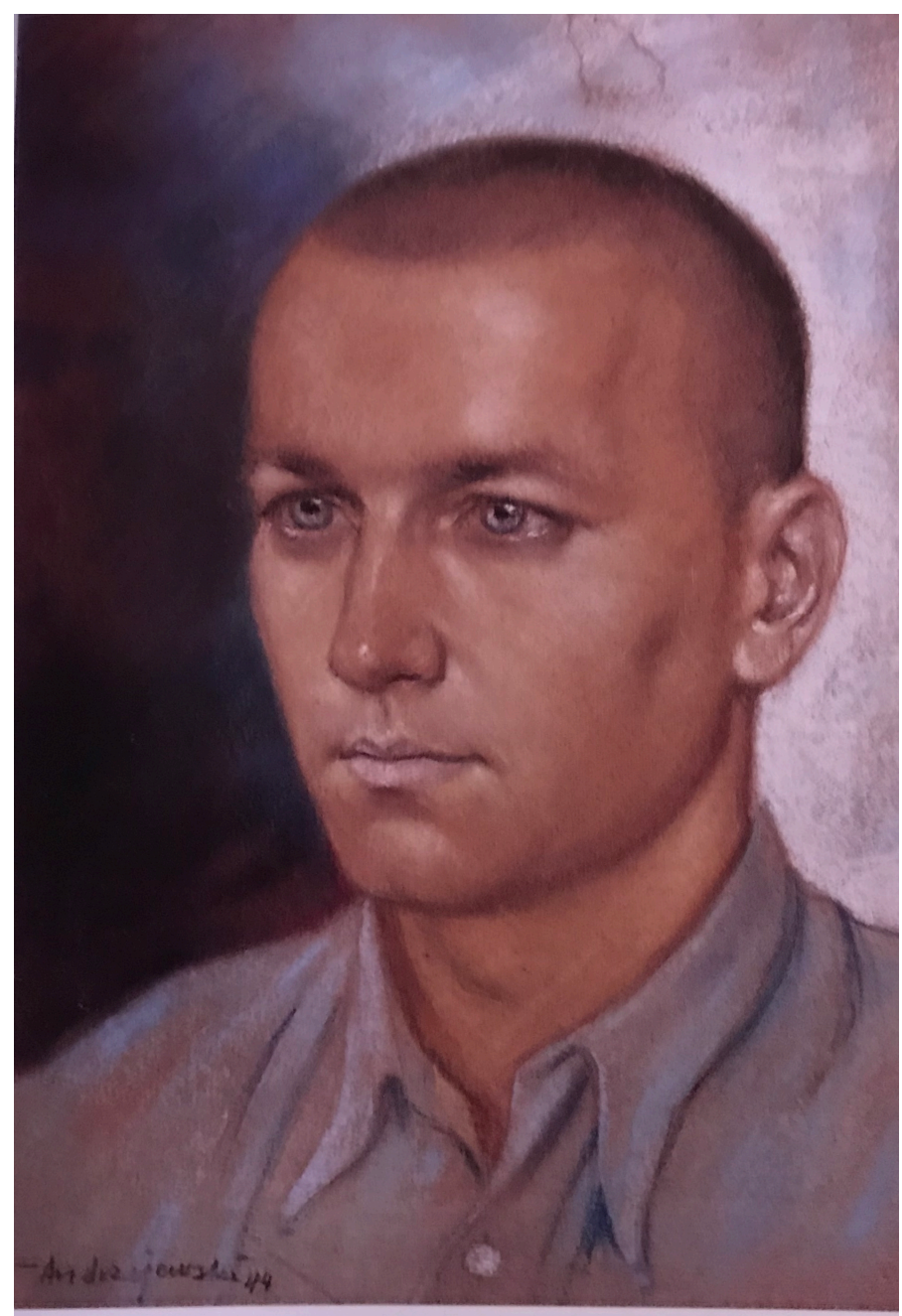

Figure 8: Pastel portrait of Maksymilian Piłat completed by Szczepan Andrzejewski in 1944 (PMO I-1-33).

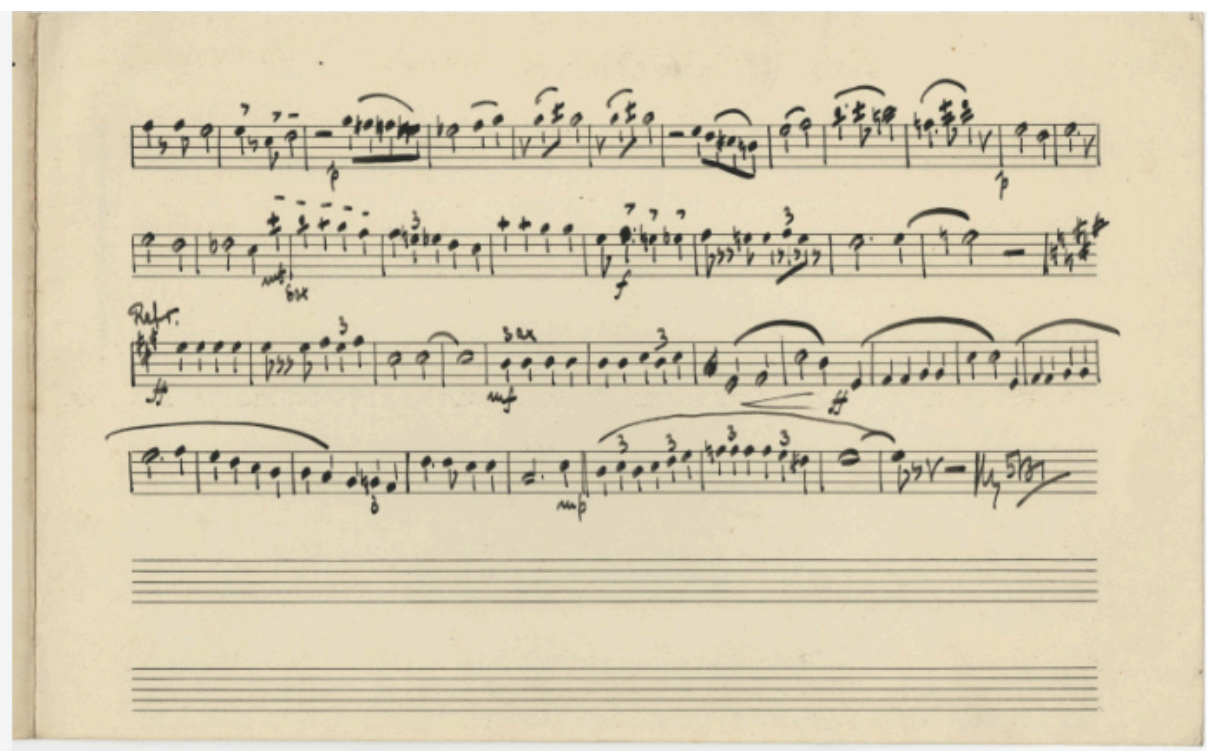

Figure 9: First clarinet part of "Die schönste Zeit des Lebens" completed by Maksymilian Piłat (PMO II-4-357/22v). 
The third copyist does not sign his prisoner number, but he created a bird at the opening of the trombone part from musical symbols (Figure 10). His refined script, with its Edward Gorey-like clefs, detached, small note heads, and right-leaning, "M-shaped" quarter note rests, could never be confused with Piłat's or Gargul's.

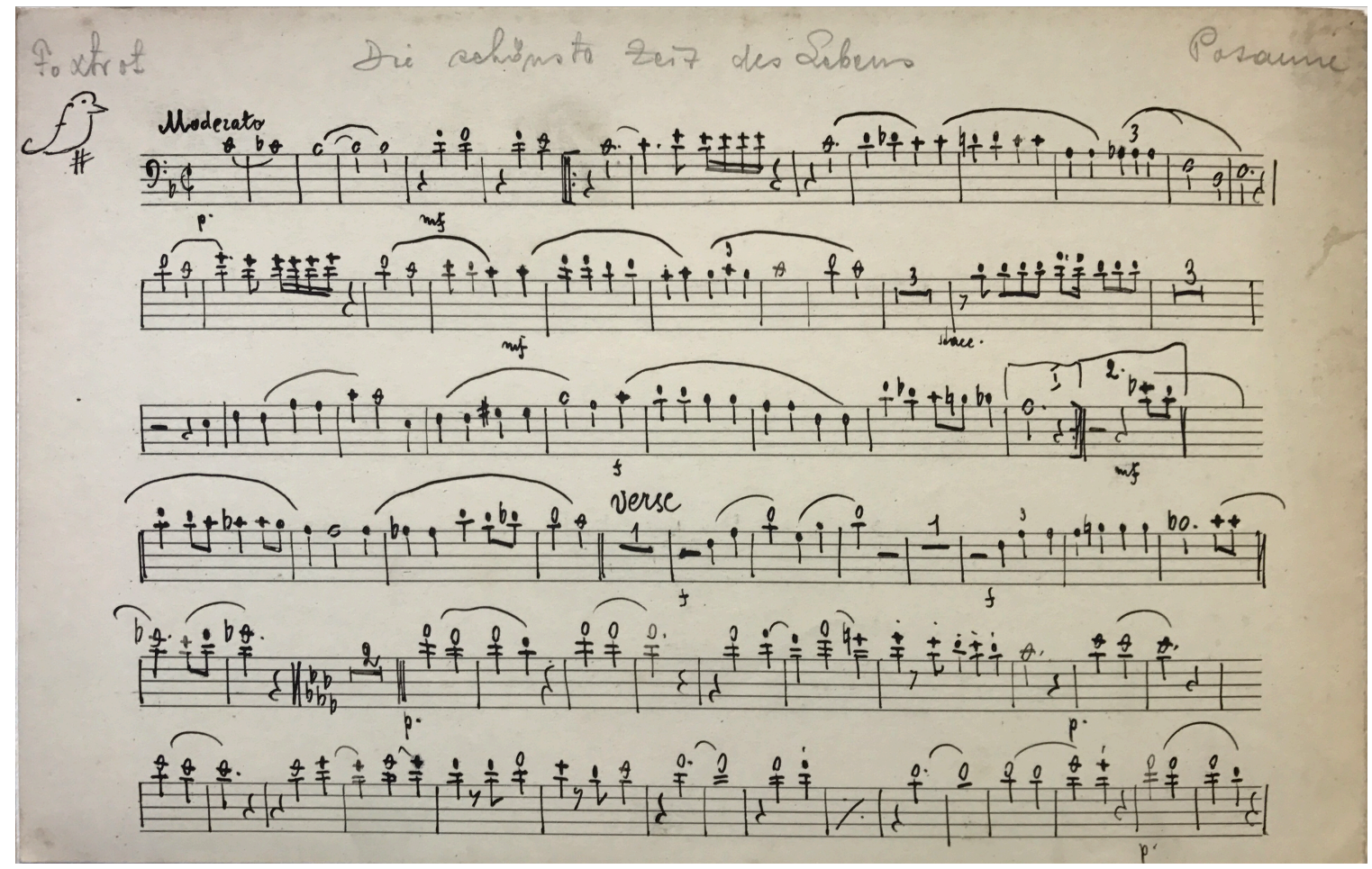

Figure 10: Trombone part for "Die schönste Zeit des Lebens" completed by an anonymous copyist (PMO II-4-357/25r).

One possible candidate would be Adam Wysocki, a tenor who also graduated from the Warsaw Conservatory and is frequently cited as a copyist by members of the Auschwitz I orchestra (Figure 11). In addition to having a degree in music theory, he was a member of the popular ensemble the Dana Choir, who recorded and appeared in films. ${ }^{16}$ Here is a short recording of Wysocki from 1935:

Audio: http://dx.doi.org/10.3998/mp.9460447.0015.101

\footnotetext{
${ }^{16} \mathrm{https://pl.wikipedia.org/wiki/Adam} \mathrm{Wysocki} \mathrm{(wokalista).} \mathrm{He} \mathrm{is} \mathrm{also} \mathrm{listed} \mathrm{as} \mathrm{playing} \mathrm{violin,} \mathrm{flute} \mathrm{and} \mathrm{double} \mathrm{bass} \mathrm{in}$ Szczepański, Häftlingskapelle, 94.
} 


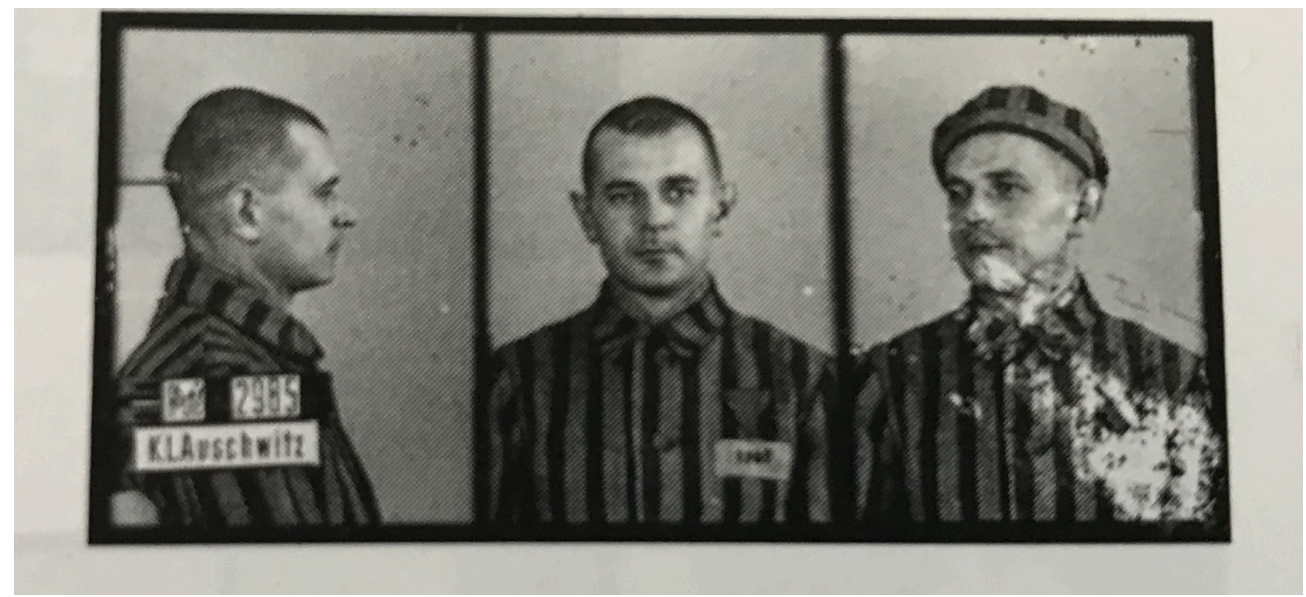

Figure 11: Prisoner photo of Adam Wysocki, number 2985. Archive of the Auschwitz-Birkenau State Museum.

An alternative might be Jerzy Vogel (vogel is the German word for bird), a pianist and later attorney who appeared with Maksymilian Piłat and four other members of the Auschwitz I men's orchestra in the documentary, Kapela Oświęcimska ${ }^{17}$ Here we see Vogel (left) and Piłat (right) in a still from the film (Figure 12). Vogel was also interviewed by the United States Holocaust Memorial Museum in 2002, when he related his experiences smuggling Jews out of the Warsaw Ghetto. ${ }^{18}$

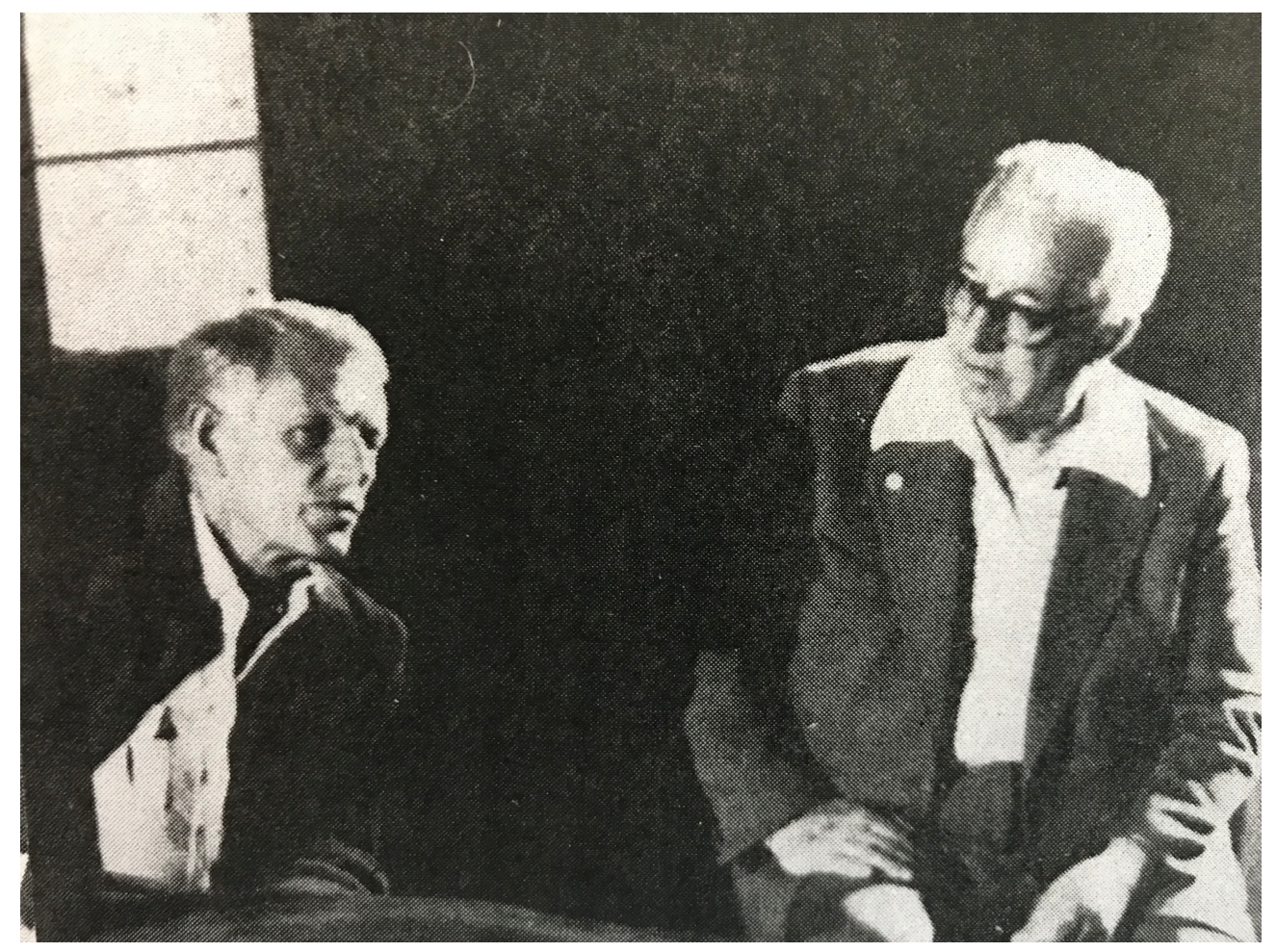

Figure 12: Still of Jerzy Vogel (left) and Maksymilian Piłat (right) from the film Kapela Oświęcimska.

\footnotetext{
${ }^{17}$ Reproduced in Szczepański, Häftlingskapelle, 72. I would like to thank Edyta Chowaniec of the Auschwitz-Birkenau State Museum for making me aware of this documentary film, https:/www.youtube.com/watch?v=BnmbB9AwmsU, as well as a later film by Szczepański, LOS Nr 129912, devoted entirely to Jerzy Vogel.

${ }^{18}$ https://collections.ushmm.org/search/catalog/.irn513209.
} 
Since all the parts are present for "Die schönste Zeit des Lebens," we have the unique opportunity of hearing - as closely as possible-what this arrangement actually sounded like when it was played in Auschwitz I. Students from the University of Michigan Contemporary Directions Ensemble, led by Oriol Sans, made a professional recording of this piece for the Auschwitz-Birkenau State Museum, reading off transcriptions of the manuscript parts. ${ }^{19}$

Audio: http://dx.doi.org/10.3998/mp.9460447.0015.101

Caption: "Die schönste Zeit des Lebens" performed by students of the University of Michigan Contemporary Directions Ensemble led by Oriol Sans.

As you can imagine, many questions arose during the editing of these manuscripts for performance: Should we remove the obviously incorrect notes? Do we adjust slurring and dynamics to match a corresponding instrument if it does not occur in the manuscript? How does one balance such unusual instrumentation? Editing the manuscript parts was a team effort by Joshua DeVries, who transcribed the parts into standard notation using Sibelius software, Oriol Sans, who conducted the ensemble, and me. Since this was an archival recording, I felt it was prudent to correct obvious errors, but to maintain the original instrumentation of the men's orchestra. Some of these errors became apparent during rehearsals and recording (a sustained G-sharp in the trombone while the other instruments play G natural). Other errors required analyzing harmonies to determine what note should logically have appeared. In one case, my viola teacher, Barbara Sturgis-Everett, determined that a double stop in the second violin notated by Gargul was physically impossible to play. And although the handwriting of the three copyists was quite clear (undoubtedly one of the reasons they were chosen as copyists), there were too many irregularities for the performers to read through effortlessly—not to mention that conventions like placing a key signature only at the beginning of a large section would have been confusing.

Since the handwriting of these three copyists is so distinctive, we can also trace their work in other arrangements that lack identifying prisoner numbers. I will now discuss briefly some other song arrangements that bear the handwriting of one or more of these prisoners.

All three collaborated again on an arrangement of "Traum von Haiti" (Dream of Haiti), a tango that uses a similar instrumentation, but with the addition of saxophones and a bass (Figure 13). Here, for instance, is Maksymilian Piłat's handwritten tenor saxophone part, which he again signs with his prisoner number (Figure 14). Although Gargul does not sign parts with his prisoner number, his handwriting is immediately identifiable by his unique quarter note rests and dividing lines between sections (Figure 15). The hand of the unidentified copyist from "Die schönste Zeit des Lebens" is also immediately recognizable by the "M" shape of his quarter note rests and the shapes of his letters in words like "Refrain" and "TangoTempo," (Figure 16). ${ }^{20}$

\footnotetext{
${ }^{19}$ This recording was made in the Duderstadt Recording Studio at the University of Michigan in October 2018. David Greenspan was the sound engineer and Chris Goosman mastered the final recording. I would like to thank Michael Haas for his invaluable feedback during the recording process.

${ }^{20}$ This arrangement also includes a second violin part and a viola part completed by a fourth prisoner and vocal parts copied by a fifth prisoner.
} 


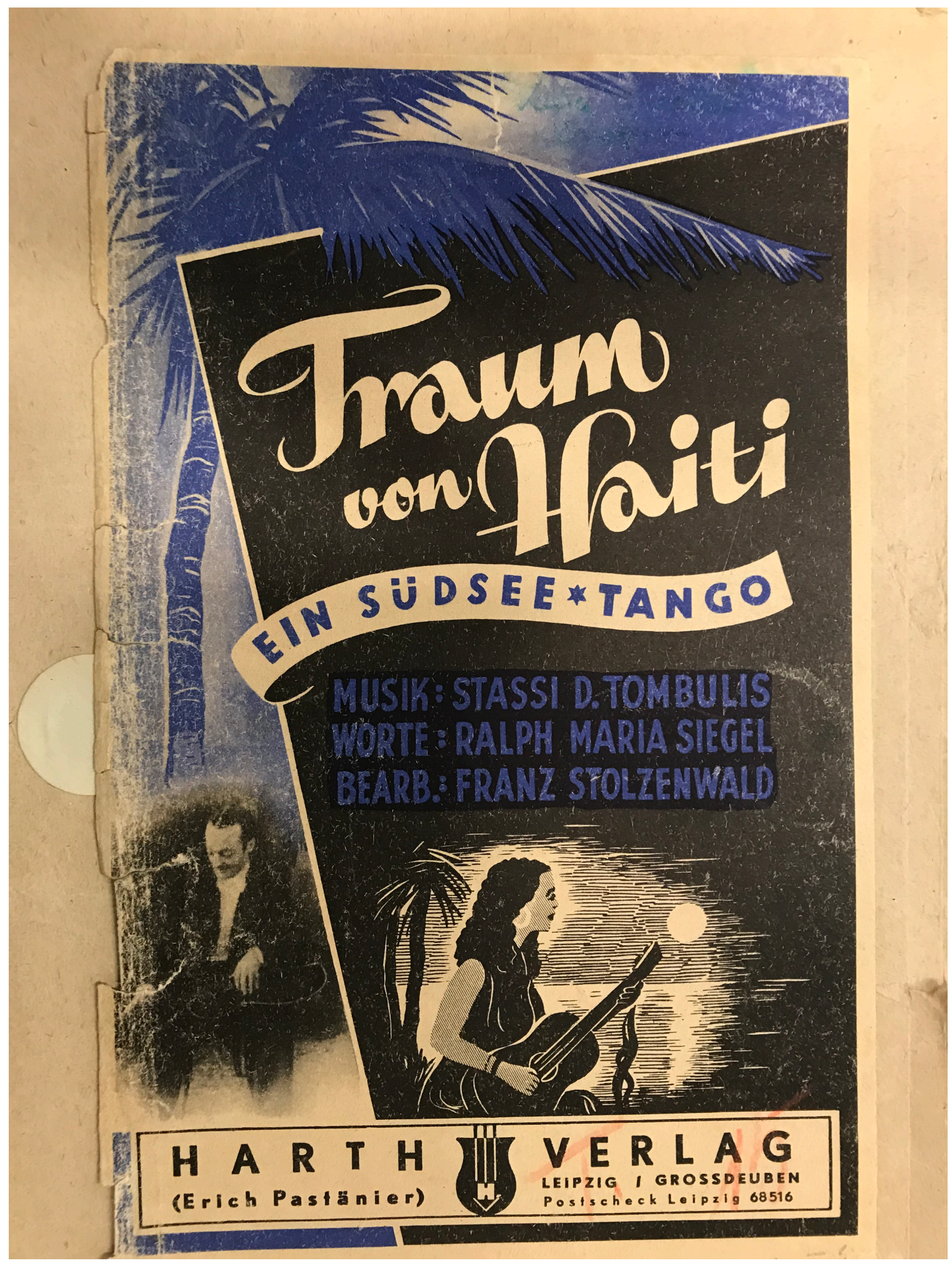

Figure 13: Cover of "Traum von Haiti" (PMO II-4-350). 


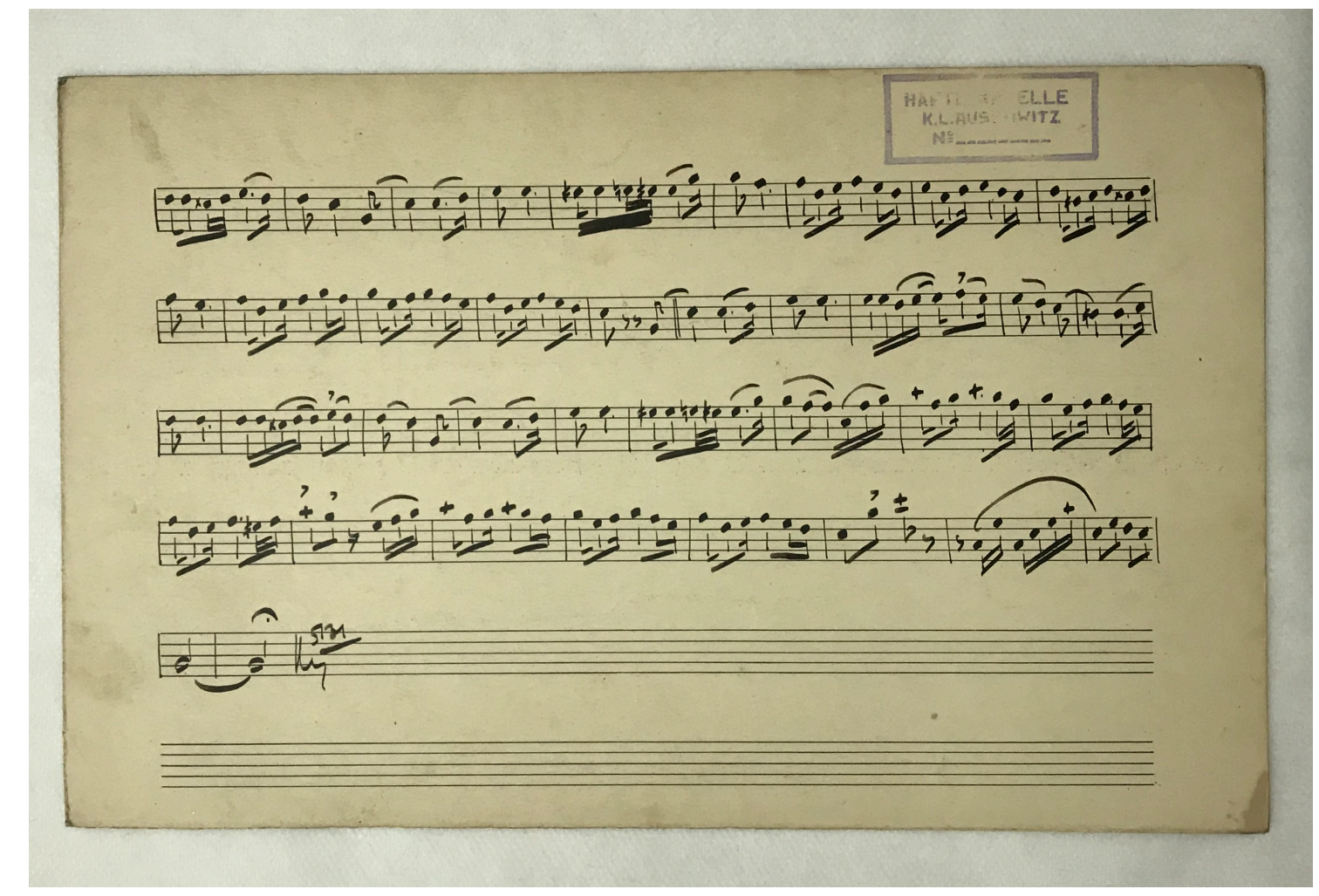

Figure 14: Saxophone in E-flat part for "Traum von Haiti” completed by Maksymilian Piłat (PMO II-4-350/47v).

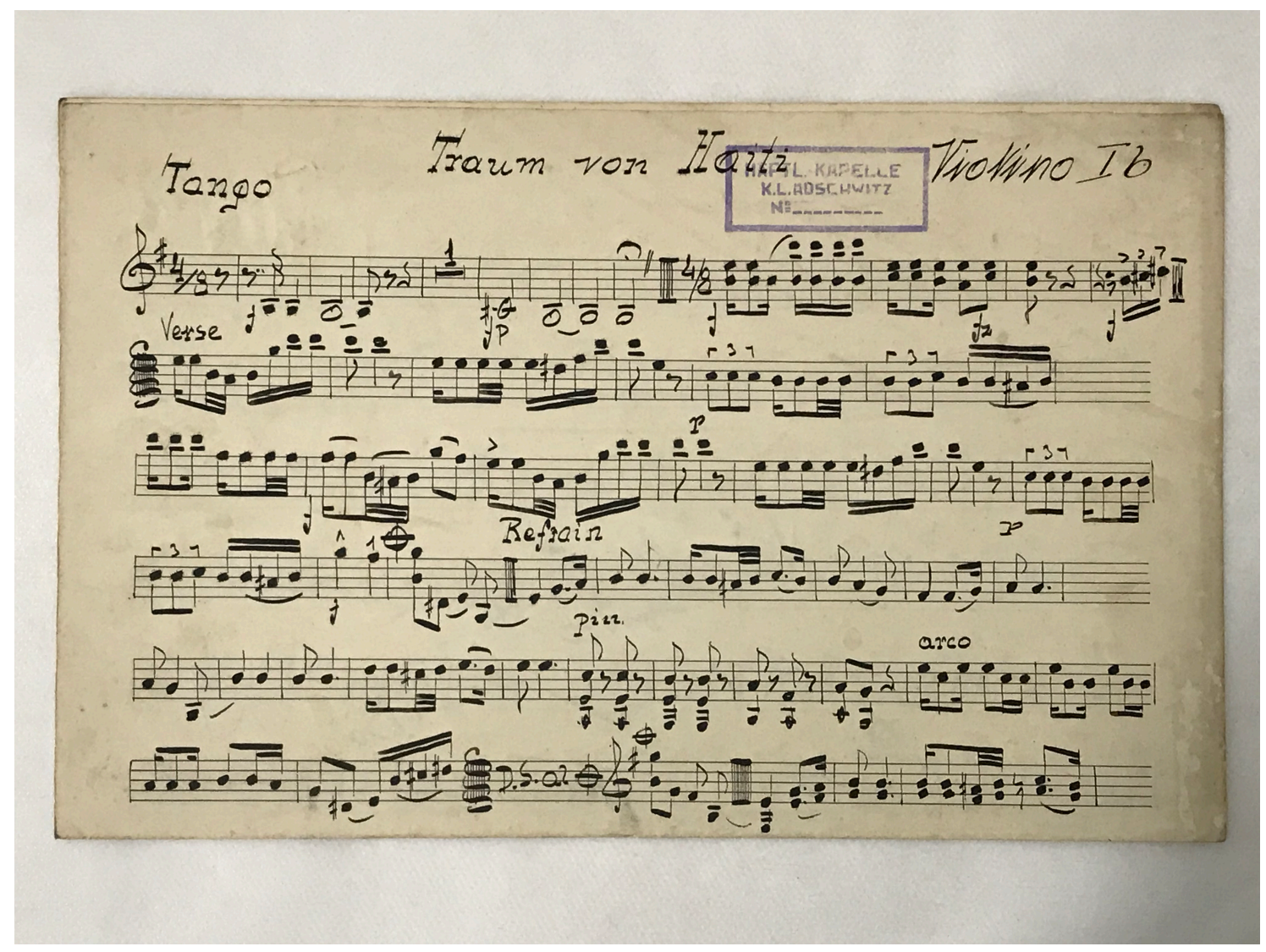

Figure 15: Violin Ib part for "Traum von Haiti” completed by Antoni Gargul (PMO II-4-350/24v). 


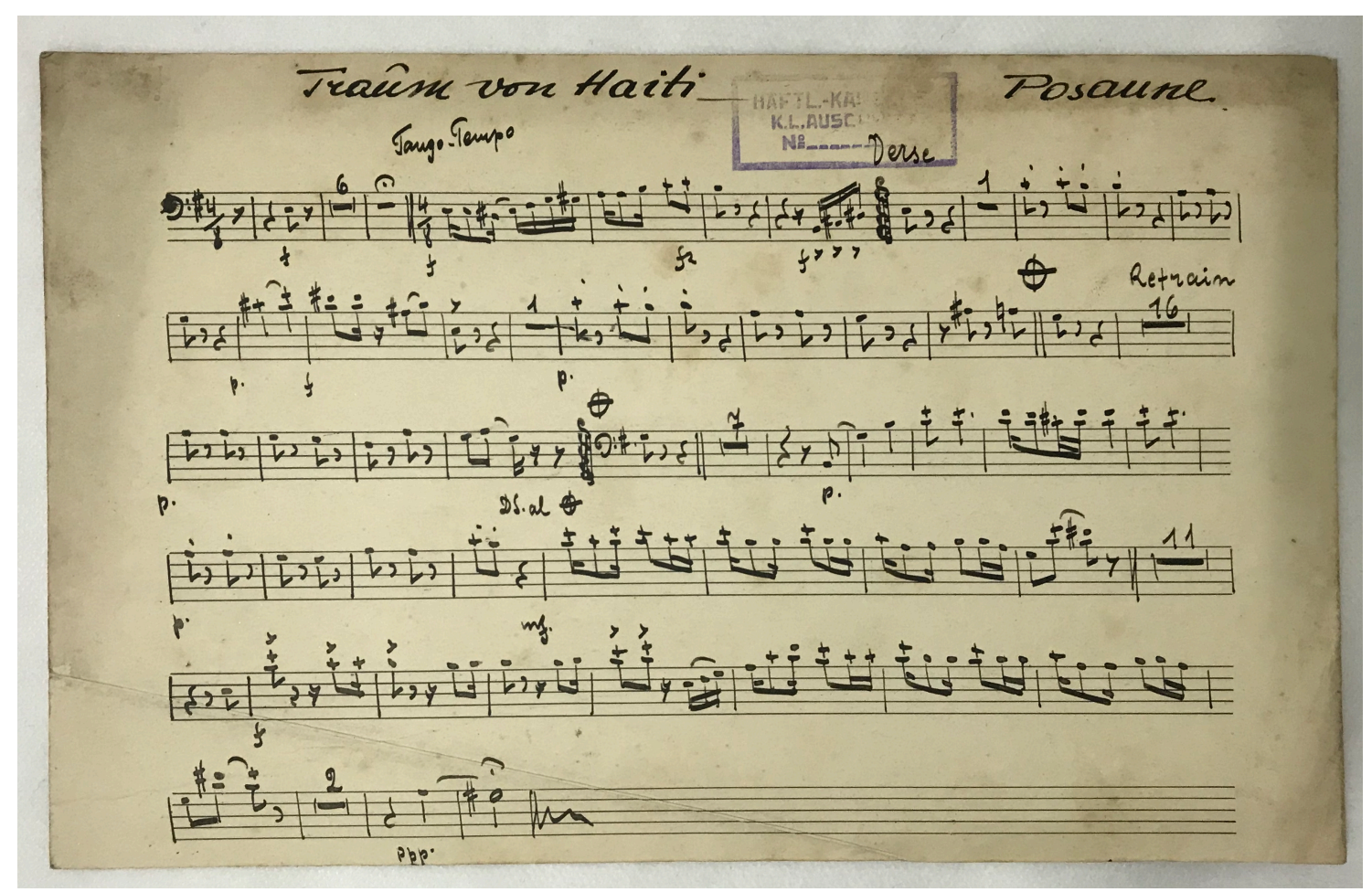

Figure 16: Trombone part for "Traum von Haiti" completed by the anonymous copyist of "Die schönste Zeit des Lebens" (PMO II-4-350/59v).

Another foxtrot, "Dideldidideldum," arranged by Maksymilian Piłat and an unknown copyist, expands the instrumentation of "Die schönste Zeit des Lebens" to a full string orchestra with tuba: eleven violins, two violas, a cello, and three double basses. The following sketch shows the successive harmonies of the song and may have been an aid in deciding the voicing of the various instruments. Note that the melodic line of the song appears in red pencil, embedded within the harmony (Figure 17).

In a third foxtrot, "Am Abend auf der Heide" (In the evening, in the meadow), Antoni Gargul completed the parts in a nearly identical orchestration to the previous foxtrot (Figure 18). The second copyist, identified through his signature by the Collections Department as Josef Kulikowski (Figure 19), was a young violinist who was imprisoned in Auschwitz I in April 1941 and transferred to Neuengamme in 1944, where he died. ${ }^{21}$

\footnotetext{
21 "Prisoners," database of the Auschwitz-Birkenau State Museum, http://auschwitz.org/en/museum/auschwitz-prisoners/. Catalog card for PMO-II-4-382.
} 


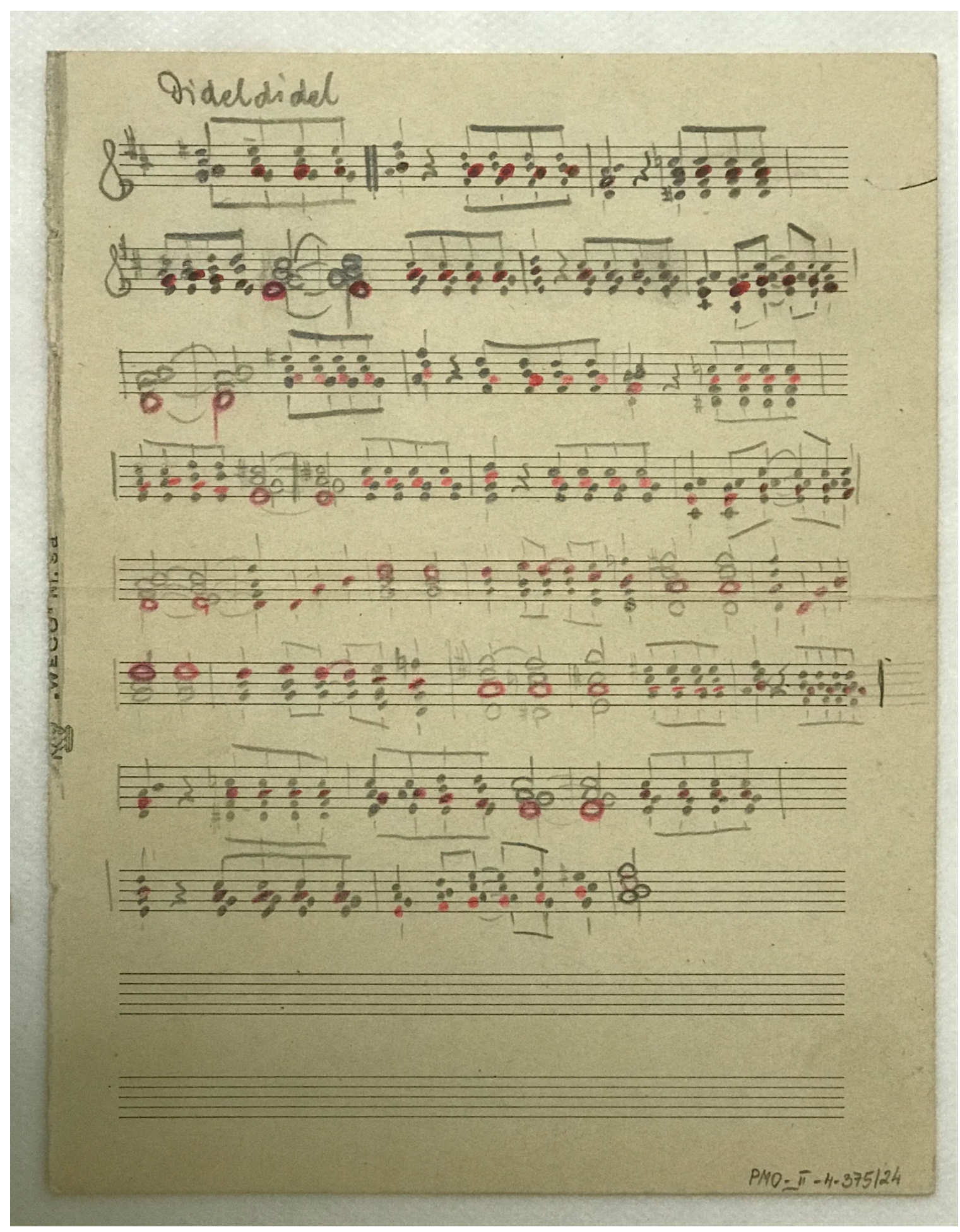

Figure 17: Harmonic sketch of "Dideldidideldum" (PMO II-4-375/24r). 


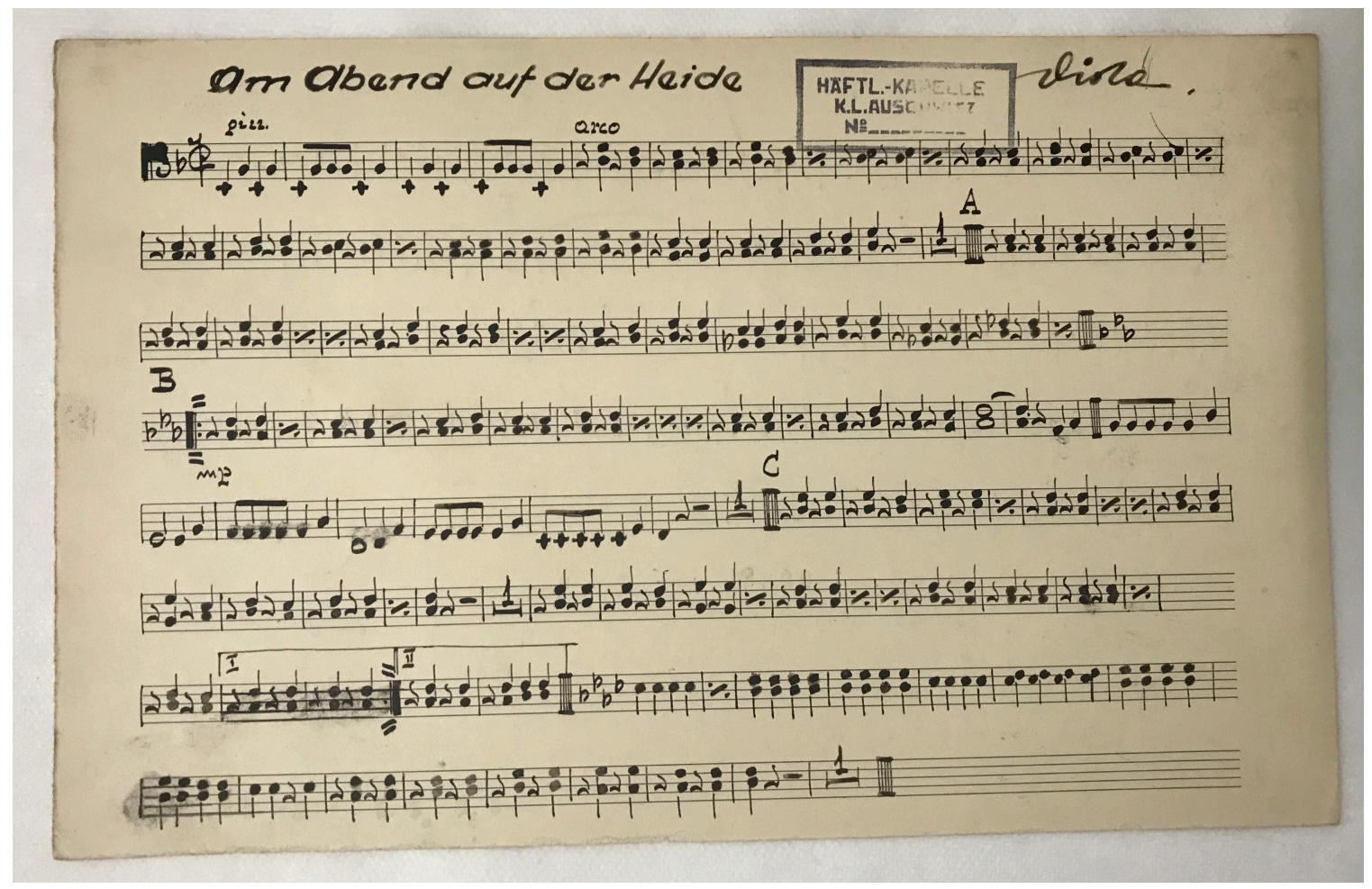

Figure 18: Viola part for "Am Abend auf der Heide” completed by Antoni Gargul (PMO II-4-382/14v).

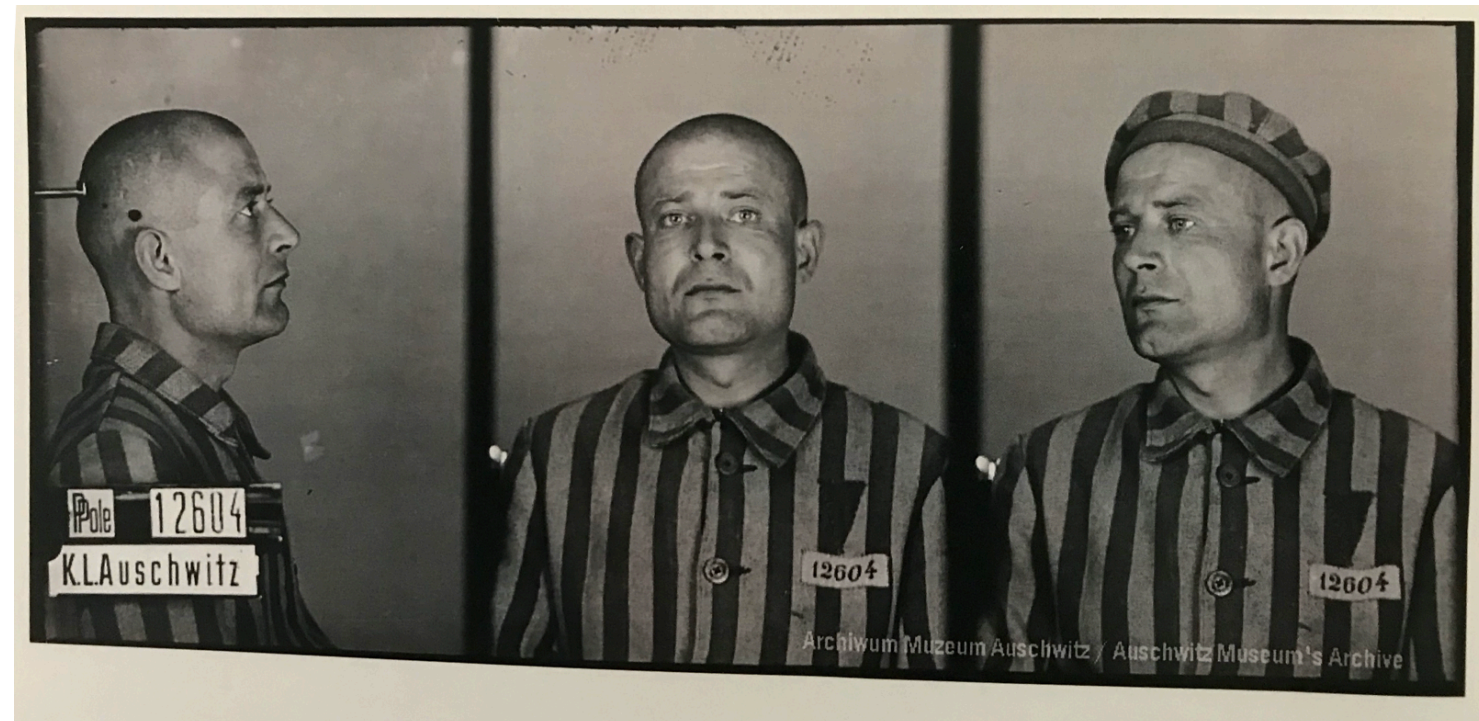

Figure 19: Prisoner photograph of Josef Kulikowski, number 12604. Archive of the Auschwitz-Birkenau State Museum.

Finally, we have manuscript parts for an arrangement of the 1941 hit song, "Ich bin heute ja so verliebt," (I'm so in love today) from the 1940 Austrian film Operette. ${ }^{22}$ It has an identical orchestration to "Die schönste Zeit des Lebens," except for an added viola, and uses the same twelve-stave manuscript paper (Beethoven Paper Nr. 31 [12 Linien]). It is also an instrumental arrangement of a popular song. In addition

\footnotetext{
${ }^{22}$ Directed by Willi Forst, music composed by Willi Schmidt-Gentner.
} 
to the three copyists for "Die schönste Zeit des Lebens," two new prisoners worked on this arrangement. One of them, Józef Kropiński, also signs his prisoner number (23468) (Figure 20).

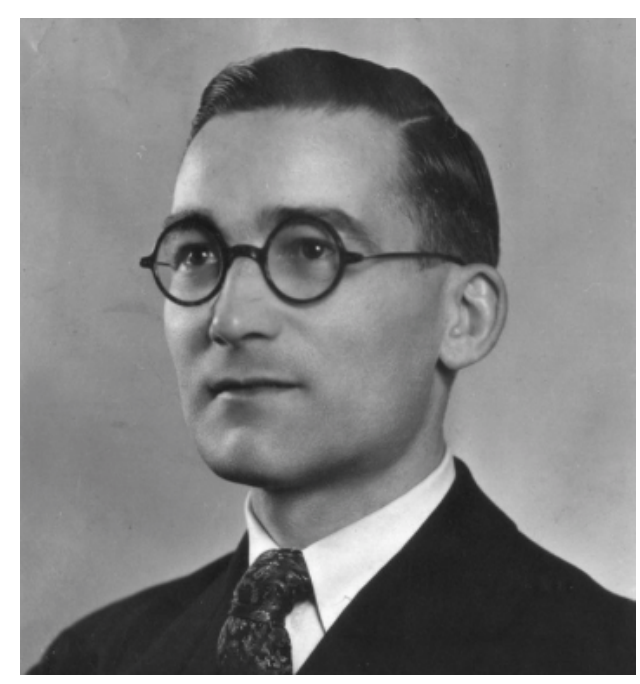

Figure 20: Józef Kropiński, prisoner number 23468.

Barbara Milewski has written extensively about Kropiński, who composed over one hundred pieces in Buchenwald. ${ }^{23}$ Based on interviews with his son, she determined that Kropiński, a violinist, was only active in the Auschwitz I men's orchestra from early April 1942 to March 10, 1943, when he was transported to Buchenwald. Although Kropiński was made a copyist as well as first violinist in the men's orchestra, a viola part of "Ich bin heute ja so verliebt" is the only surviving manuscript in the collection that bears his handwriting (Figure 21).

Even after studying this small group of manuscripts, we can make the following conclusions: 1) The repertoire gravitated toward recent hit songs that could function as dance music (tangos, waltzes, foxtrots); 2) The parts tend to be copied by prisoners who played the corresponding instrument: Antoni Gargul completed viola parts, Maksymilian Piłat clarinet parts, and Josef Kulikowski violin parts; and 3) The copyist-arrangers found both an instrumentation and arranging solution that was successful and applied it to multiple pieces. For instance, the second violin invariably plays double stops, as does the viola. The first violin is always a melodic instrument, and the tuba alternates between the root and fifth of the harmony. What might appear initially as a bizarre combination of instruments, perhaps assembled out of necessity, produced a unique but attractive sound that in fact increased the emotional quality and poignancy of these songs.

\footnotetext{
${ }^{23}$ Barbara Milewski, “Józef Kropiński," Lexikon Verfolgter Musiker und Musikerinnen der NS-Zeit (2012), https://works.swarthmore.edu/fac-music/53; and "More Music for the Kinohalle! Józef Kropiński's Compositions in the Buchenwald Concentration Camp," OREL Foundation (2012) https://works.swarthmore.edu/fac-music/54.
} 


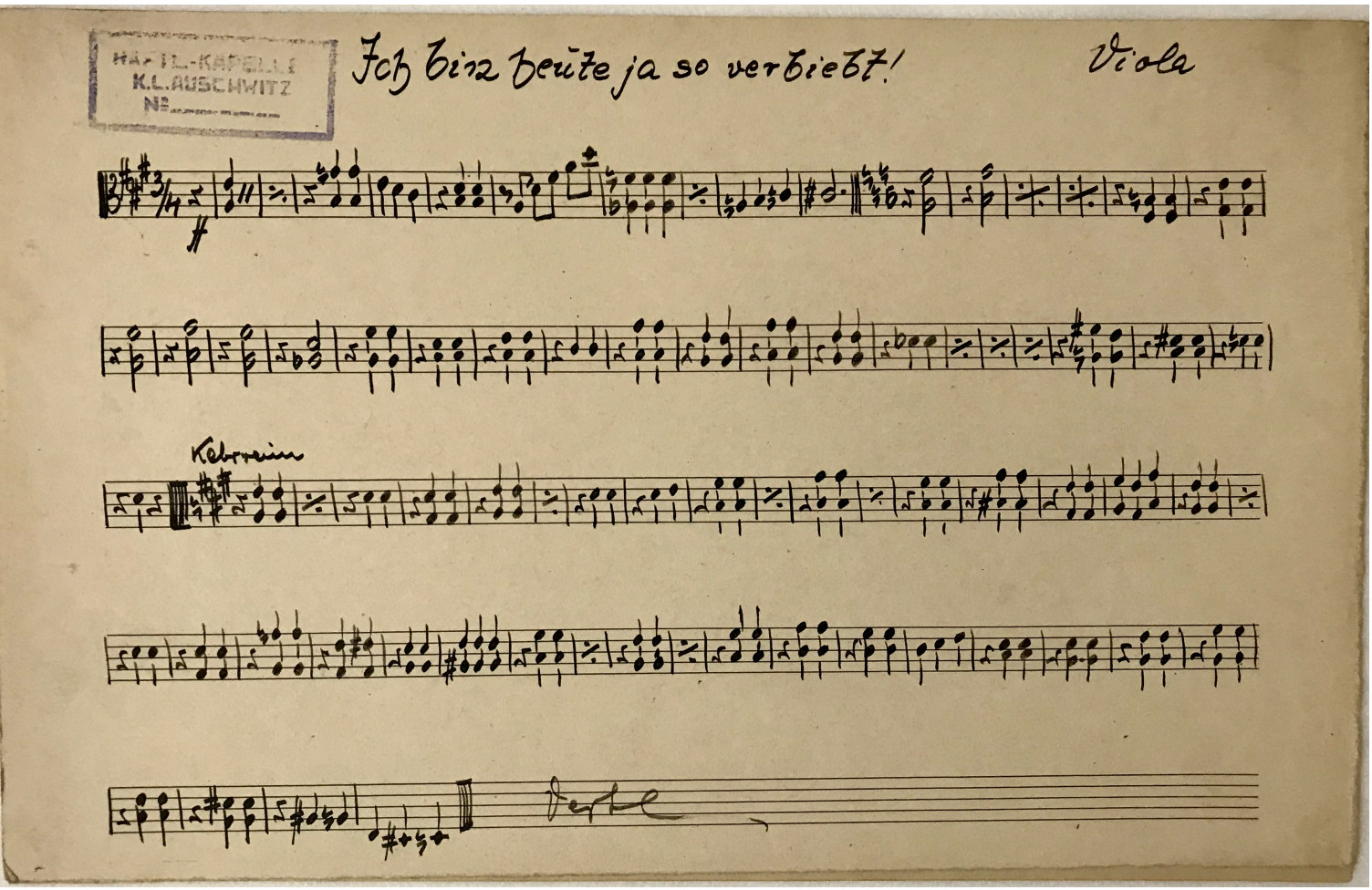

Figure 21a

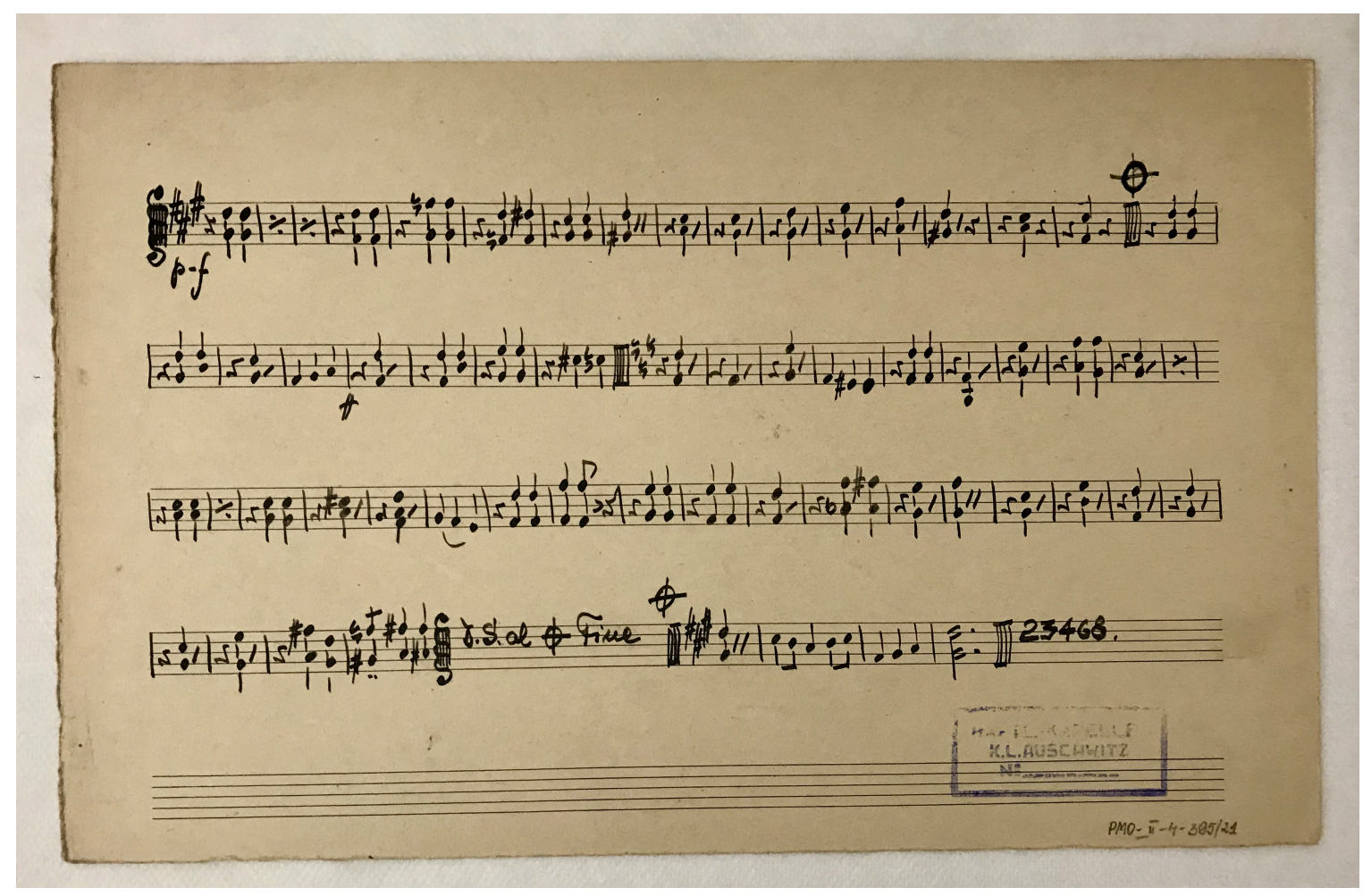

Figure 21b

Figure 21a and b: Viola part for "Ich bin heute ja so verliebt" completed by Józef Kropiński (PMO II-4-395/21r and v). 


\section{Chronology of the Auschwitz Manuscripts}

The Auschwitz I orchestra had its first rehearsal on January 6, 1941, and dissolved on January 18, 1945. It was ephemeral—as were the lives of its musicians. ${ }^{24}$ In Häftlingskappelle, Makzymilian Piłat revealed, "The worst was when Palitzsch appeared when we were playing. Then it was obvious that he was going to take someone out of the orchestra and lead him to Block 11. As far as I remember, he took out around fifty people from the orchestra and shot them. Personally." ${ }^{25}$ Only $50 \%$ of the Polish political prisoners survived Auschwitz. ${ }^{26}$ The list of musicians in the orchestra in November 1944 published by Jacek Lachendro shows an almost complete turnover from those listed in Häftlingskappelle (Figure 22).

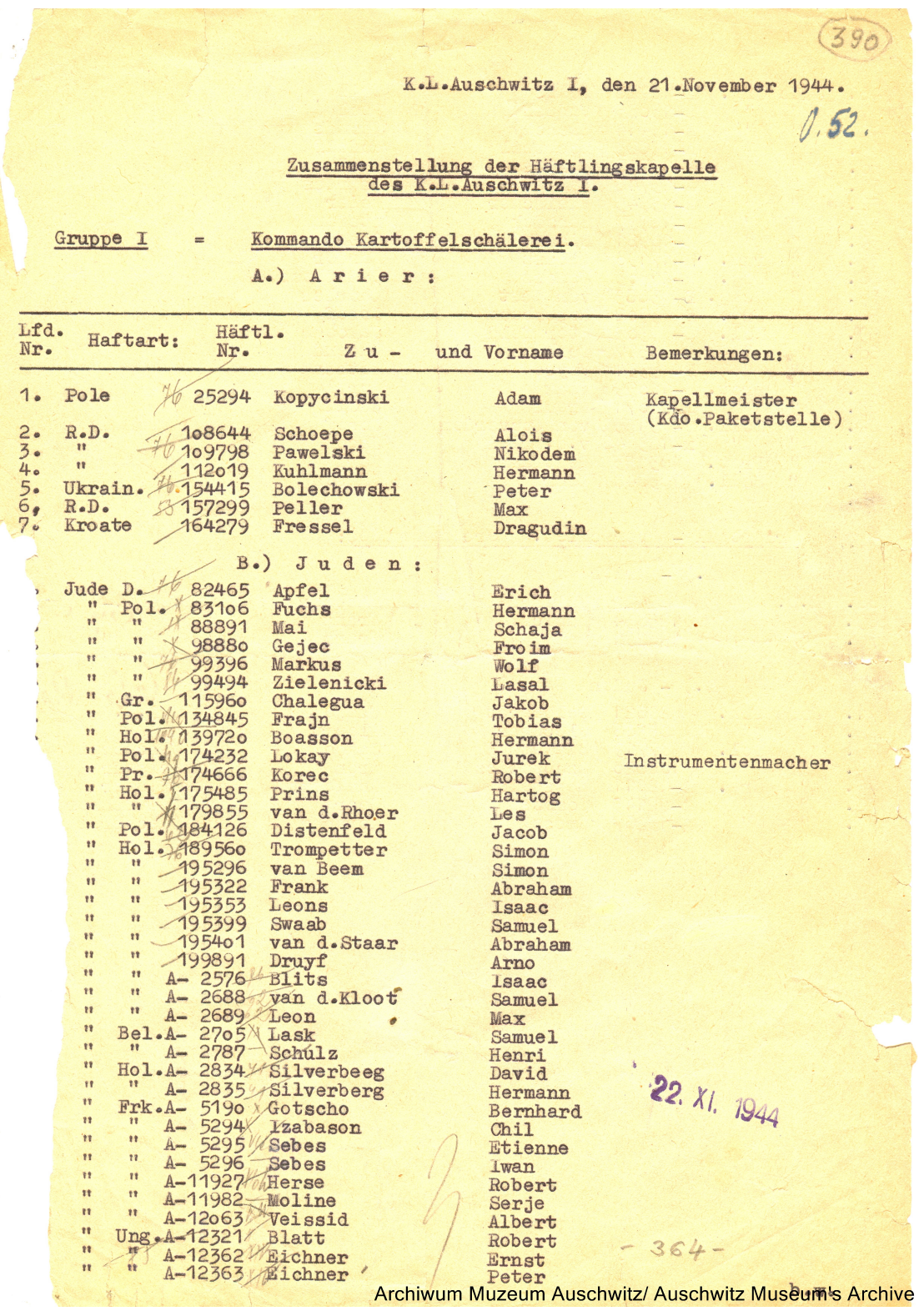

\footnotetext{
${ }^{24}$ Danuta Czech, Auschwitz Chronicle 1939-1945 (London: I. B. Tauris \& Co., Ltd, 1990), 44; Szczepański, Häftlingskapelle, 26.

${ }^{25}$ Szczepański, Häftlingskapelle, 71.

26 "Poles in Auschwitz," database of the Auschwitz-Birkenau State Museum, http://auschwitz.org/en/history/categories-of-prisoners/poles-in-auschwitz/.
} 


\section{Figure 22a}

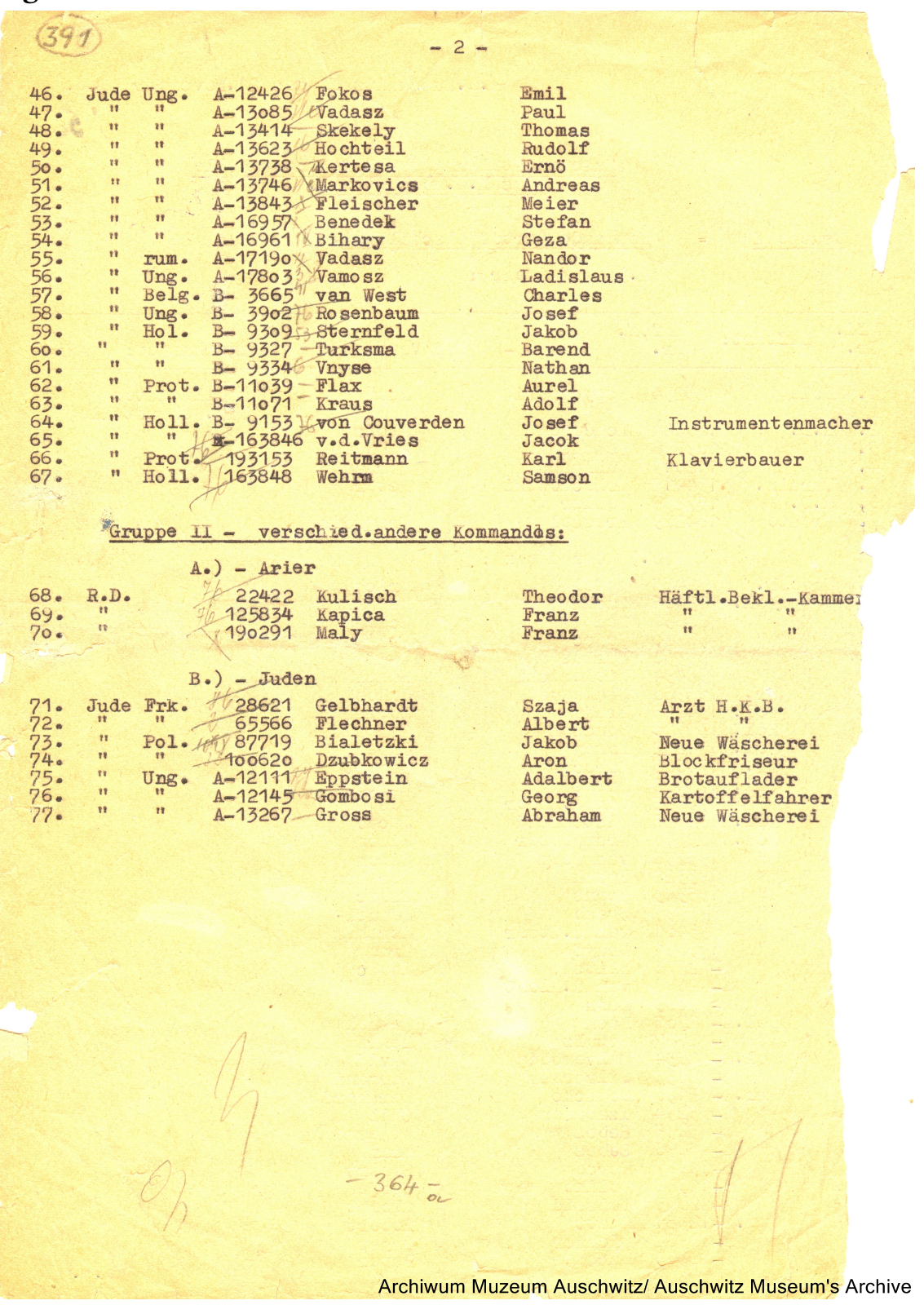

Figure 22b

Figure 22a and b: List of members of the Auschwitz I men's orchestra, dated November 21, 1944, and stamped November 22, 1944, published in Jacek Lachendro's "The Orchestras in KL Auschwitz."

Jewish prisoners were finally allowed to play in the orchestra and make up 67 of the 77 members. Yet most of the prisoner copyists survived, despite being sent to other concentration camps in October 1944. Taking into account the publication dates of the popular songs, the complex instrumentation requirements, and the fact that Antoni Gargul was released in October 1943, it is likely that many of these arrangements were completed in either 1942 or ' 43 . One of the few dated sources is signed by Józef Sitko, a cellist and lieutenant colonel in the Polish army, and bears the date January 5, 1943. (Sitko was brought to the camp less than two months before on November 18, 1942.) $)^{27}$

\footnotetext{
${ }^{27}$ PMO-II-4-358, 11r; Catalog card for PMO-II-4-358; "Prisoners," database of the Auschwitz-Birkenau State Museum http://auschwitz.org/en/museum/auschwitz-prisoners/.
} 
More important, perhaps, than the date of these arrangements, is discovering how such escapist popular songs and dance numbers functioned in a concentration camp. Popular songs and foxtrots were indeed played by the camp orchestras as prisoners marched to and from work. Primo Levi, for instance, recounted, "A band begins to play, next to the entrance of the camp: it plays Rosamunda, the well-known sentimental song, and this seems so strange to us that we look sniggering at each other; we feel a shadow of relief, perhaps all these ceremonies are nothing but a colossal farce in Teutonic taste. ${ }^{28}$ Commenting on the women's orchestra, the prisoner Romana Duraczowa complained, "The camp orchestra in Birkenau is playing lively marches, popular foxtrots. It's enough to make your belly ache. How we hate that music and those musicians." ${ }^{29}$ However, if we look at the instrumentation of the Auschwitz I arrangements, with their large string sections and occasional exotic instruments, they do not conform to the instruments that accompanied marching prisoners, which always included a bass drum and cymbals. A number of them are waltzes, whose simple triple meter would make marching impossible; moreover, several include texts with vocal lines. How, then, were they used?

In Jacek Lachendro's exemplary study of the orchestras in the Auschwitz concentration camp complex, he explains: "The orchestra also had the task of entertaining members of the Auschwitz garrison and their families. The venue ... was the square near Commandant Höss's villa. . . The orchestral performance was made up of three hour-long segments containing classical, opera, and operetta music, as well as the latest dance hits." ${ }^{30}$ In Häftlingskapelle, the percussionist Czesław Sowul also mentions a dance band of approximately twenty players. ${ }^{31}$ In the opening of the film Kapela Oświęcimska, Adam Kopycinski views the area near Höss's villa where the concerts formerly took place:

He suddenly smiles, and looks at a hill overgrown with bushes and the centrally located Höss gallows. 'It all used to look very funny: shaved heads, striped uniforms, everybody in clogs and with their own instrument. And at the end of the column, the prisoners carrying a black pianoforte like an enormous coffin. We had to carry everything ourselves, from the music room to the place where the concert would take place. We would set up in this square in front of the Höss villa. They hadn't funded the gallows for him yet, so they were not there, $\ldots$. and we would play for three to four hours." 32

Further commenting on the proximity of this location to Crematorium I, he notes, "Sometimes when we played on this elevation in front of the Höss villa, in this breezy concert hall, the smoke from the crematorium terribly irritated my colleagues. It would fill the air with stench. From time to time, such a cloud of smoke would come over that it was literally hard to see the notes."33

In conclusion, while there is frequent reference to repertoire played in Auschwitz-Birkenau, both in prisoner testimonials and academic studies, actually examining the manuscripts gives us critical details about instrumentation, the prisoners who copied and arranged the parts, and the resulting unique sound. Given that these arrangements were performed primarily for the SS and other members of the garrison, the titles are not as ironic as they originally seemed, although, as the war progressed, perhaps they began to seem ironic even to them.

\footnotetext{
${ }^{28}$ Primo Levi, Survival in Auschwitz. The Nazi Assault on Humanity (New York: Simon \& Schuster, 1996), 30.

${ }^{29}$ Laks, Music of Another World, 116.

${ }^{30}$ Lachendro, "The Orchestras in KL Auschwitz," 40.

${ }^{31}$ Szczepański, Häftlingskapelle, 71.

${ }^{32}$ Szczepański, Kapela Oświęcimska, https://www.youtube.com/watch?v=BnmbB9AwmsU, accessed July 15, 2019. Text reproduced in Häftlingskapelle, 48. I thank Barbara Alvarez for translating the passages in this article from Polish to English, as well as translating innumerable Polish documents that I had to consult in my research.

${ }^{33}$ Szczepański, Häftlingskapelle, 85.
} 


\section{Bibliography}

Czech, Danuta. Auschwitz Chronicle 1939-1945. London: I. B. Tauris \& Co Ltd, 1990.

Kaumkötter, Jürgen. Kunst in Auschwitz 1940-1945. Berlin: Rasch Druckerei und Verlag, 2005.

Laks, Szymon. Music of Another World, trans. Chester A. Kisiel. Evanston, IL: Northwestern University Press, 1989.

Lachendro, Jacek. “The Orchestras in KL Auschwitz.” Auschwitz Studies 27 (2015): 7-148.

Levi, Primo. Survival in Auschwitz. The Nazi Assault on Humanity, trans. Stuart Woolf. New York: Simon \& Schuster, 1996.

Milewski, Barbara. "Józef Kropiński.” Lexikon Verfolgter Musiker und Musikerinnen der NS-Zeit (2012). https://works.swarthmore.edu/fac-music/53.

."More Music for the Kinohalle! Józef Kropiński’s Compositions in the Buchenwald Concentration Camp.” OREL Foundation (2012). https://works.swarthmore.edu/fac-music/54.

Schäfer, Wolfgang. Franz Grothe Werkverzeichnis, Neue erweiterte Ausgabe. Munich: Buch \& Media $\mathrm{GmbH}, 2008$.

Szczęśniak, Hubert. "Musical Sources Survived in the Collection of the Auschwitz-Birkenau State Museum.” Kwartalnik Młodych Muzykologów UJ35, no. 1 (2017): 127-77.

Szczepański, Ignacy. Häftlingskapelle. Warsaw: Książka I Wiedza, 1990.

—. Kapela Oświęcimska. YouTube video. https://www.youtube.com/watch?v=BnmbB9AwmsU. 